\title{
Incomplete Federalism: Jurisdiction Over Antitrust Matters in the European Economic Community
}

\author{
Richard M. Buxbaum*
}

$\mathrm{I}^{\mathrm{N}}$

N THE United States only the federal courts and agencies are empowered to apply the federal antitrust laws. ${ }^{1}$ In the European Economic Community the judicial and administrative organs of the Member States are empowered to apply Community antitrust law, but share these powers to some extent with the Commission of the EEC. ${ }^{2}$ The Commission, indeed, enjoys primacy in applying articles 85 and 86 of the Rome Treaty, but to an uncertain degree. Harmony in decision-making between these Community and national institutions may be achievable through the Court of Justice of the European Communities, but again to an uncertain degree. This article explores these problems of degree. It is part of the recently described discussion concerning the federal characteristics of the onrushing Common Market. ${ }^{3}$ Thus it may be of interest as a comparative

* Acting Associate Professor of Law, University of California School of Law, Berkelcy. I am indebted to the Committee on International Legal Studies of the School of Law and to the Institute of International Studies at Berkeley for financial assistance in the preparation of this article.

1 Sherman Act \$ 4, 26 Stat. 209 (1890), 15 U.S.C. \$ 4 (1958); Clayton Act \$\$ 11, 15, 38 Stat. 731, 736, 737 (1914), 15 U.S.C. $\$ \$ 15,22,26$ (1958). State courts are not competent here except when an issue under these laws arises in and is necessary to the disposition of an action based upon other riglits. Bement v. National Harrow Co., 186 U.S. 70, 87-88 (1902); cf. Pratt v. Paris Gas Light \& Coke Co., 168 U.S. 255, 259 (1897).

2 It would unduly extend this article to recapitulate the basic information concerning the system and purposes of the European Economic Community's antitrust Iaws. For a bibliograplyy of the more comprehensive recent discussions, see Riesenfeld, Antitrust Laws in the European Communities: A Sequel, 50 CaLIF. L. Rev. 829, $830 \mathrm{nn} .13$ \& 14 (1962). For an eartier descriptive review, see Buxbaum, Antitrust Regulation Within The Eutopean Economic Community, 61 Colons. L. Rev. 402 (1961). Of the more recent discussions, see especially Becker, Effect of the Common Market "Antitrust" Law on American Companies, 8 AnTitrust BuLL. 3 (1963); Ladas, Antitrust Law in the Common Market with Special Reference to Industrial Property Agreements, 23 Oнто Sr. L.J. 709 (1962).

3 Hay, Federal Jurisdiction of the Common Market Court, 12 Ax. J. Comp. L. 21 (1963).

A note on citations: Regulations of the Commission of the EEC, as well as of the Council of Ministers, are published in an official gazette printed in four editions, one in each of the official languages. References will be to the French version, JouRNaL OFFICIEx DES COMmUNAUTÉS EUROPÉENNES [hereinafter cited as J.O.C.E.].

The German periodical WIRTSceaft UND WeTtBewerb [hereinafter cited as WUW] compiles reasonably comprehensive German and European Commumities ease reports in a continuous sequence under several headings, as WUW/E for "Entscheidungen," or decisions; thus WoW/E BGH (Federal Supreme Court); WoW/OLG (Appellate District Court); WoW/E BKartA (Federal Cartel Office); etc. A compreliensive commentary on the EEC antitrust laws by Deringer et al. has been appearing serially in WUW; it is in the form of anno- 
review of problems resembling those arising under the American division of powers between state and federal governments. More immediately and practically, it may also be useful to American enterprises operating in the Common Market; it suggests a previously neglected emphasis on the role of national as distinguished from Community institutions in the regulation of anti-competitive practices.

Defining the competence of these institutions is as important as it is complicated. It is complicated for several reasons. First, the Community body, the Commission, has the exclusive and highly discretionary power to grant administrative exemption from the Community antitrust laws to particular restrictive arrangements. As a result of this power a certain compromise with strict antitrust principles is inevitable, a conpromise that may in time resemble the American treatment of some regulated industries. Many supporters of the Community development would assert that this situation is not inerely expectable but desirable. ${ }^{5}$ Because of the administrative process that has been devised to exercise this discretionary authority, a long period of uncertainty over the application of these antitrust provisions is also inevitable. The Commission's self-policing application scheme will require several years before all presently submitted agreements have been reviewed and either approved for exemption or condemned.

On the other hand, the participants in many of these agreements may wish to enforce or avoid them in the national courts before the Commission has acted. Since these courts cannot grant exemptions to otherwise

tations to each article of the various Community enactments; for example, Deringer, Kommentar EWG-Vertrag VO Nr. 17 Art. 9 Anmerkung 14 [Commentary to Regulation No. 17, Art. 9, Annotation 14]. Since all references herein are to article 9 of Regulation No. 17, the work will hereinafter he cited as Deringer, Kommentar, with the particular annotation given in parentheses following the WoW citation.

4 See Camps, The European Common Market and Free Trade Area, in PrInceton UnIversity Center of International Studies, Memoranduar No. 15 (1957).

- As an example, compare the following excerpt from the official position of the Economic and Social Committee of the European Parliament (to the so-called Action Programme, note 13 infra), in its Report of October 30, 1963, reprinted in 6 J.O.C.E. 3022 (Dec. 29, 1963): "On the other hand, the Committee points to the fact that the principle of competition is to be viewed within the framework of the overriding general treaty aims as prescribed in article 2. These aim at an harmonious development of econonnic life, a consistent and orderly expansion, a greater stability and an accelerated biting of the standard of living. The execution of the principle of competition can in individual situations contradict the realization of these overriding treaty aims, so that a relative evaluation [of each] becomes necessary. In the Committee's opinion the resolution of this collision can only be achieved by separating the good from the bad in each case, taking into account the economic consequences of a restrictive practice. A fair and realistic ["wirtschaftsnahe"] interpretation of the prohibitions as well as of the exemption criteria offers an adequate basis for this task." Id. at 3023. (Author's translation.)

See also VerLoren van Themaat, Current Antitrust Developments in the European Common Market and the Relation Thereto of Industrial Property Rights, 6 PAT. TRADEM. \& Coprr. J. RESEARCE \& ED. 429, 433 (1963). 
illegal agreements, a dilemma arises. Either their decisions will have an unjustifiable impact upon later action of the Commission, or they will feel barred, again unjustifiably, from proceeding and will thus deprive private parties of remedies that the national law grants them. Finally, while a possibility does exist of harmonizing potentially contradictory approaches through the use of the Court of Justice, it is not likely to materialize in the near future, for reasons further explored in this article.

The importance of a clear delimitation of national and Community competence lies in these same reasons. Unless the national courts understand and exercise their full powers, detrimental effects upon private litigation will follow. The present typical organization of trade and industry in Europe, especially in the distributive sector, ${ }^{6}$ has particularly felt the impact of Community antitrust law. The resulting tensions, as well as those arising fronl changing distribution patterns, ensure and have already caused considerable private litigation. Thus, the effects of confusion will not be merely academic. ${ }^{8}$ These same pressures can be expected to lead national courts to resist any interpretation of Community law that might hamper unduly the disposition of such litigation. This article will take such resistance into account in describing some of the obstacles that may obstruct present moves toward completely centralized enforcement. By the same token, the description and analysis of the present legal situation that begins this article will stress the desirability of interpretations of statute and regulation that would leave a reasonable measure of powers in the national courts. The cases that follow indicate why such a conservative approach is justified.

Some personal predilections or grounds of principle for welcoming a cautious beginning to centralization cannot be avoided. Good intentions assumed, the unique nethod of operation imposed upon the Commission ${ }^{0}$ explains its seeming lack of a direct enforcement record to date ${ }^{20}$ and its

${ }^{6}$ See the series entitled Marketing In Europe, published by The Economist at irregular intervals, and especially "Resale Price Maintenance in the Coinmon Market" (1963); 1 IFO INSTITUT Für WIRTSCHAFTsForschuNG, PREISBINDUNGEN IN DER WESTDEUTSCHEN WIRTSCEAFT, tables following p. 226 (1962).

T See especially Regulation No. 153, 5 J.O.C.E. 2918 (Dec. 24, 1962) ; id. at 2921 (appended announcement).

${ }^{8}$ As an example, see Goldstein, Administrative Shaping of French Refusal to Deal Legislation, 11 Asr. J. CoMp. L. 515, 536-37 nn.53 \& 54 (1962). See the discussion in text accompanying note 56 infra.

${ }^{9}$ For a description and critique, see Buxbaum, Patent Licensing: A Case Study in Autitrust Enforcement in the EEC, to be published in 9 ANTrTRUsT Butr. ...... (1964) (No. 1).

10 For the Commission's actual record, see its report in 6 Butc. E.E.C. 49 (No. 9/10, Sept./Oct. 1963). For a full description of the Commission's workload generally, and its efforts to master a great number of assignments, see Stein, Assimilation of National Laws as a Function of European Integration, 58 AM. J. INT'L L. 1, 35 (1964). 
avowed intention to proceed cautiously. ${ }^{11}$ Hence, there must be a search for alternative enforcement routes. Moreover, the weakness of the Commission's political base ${ }^{12}$ and its lack of power to supervise the important structural changes in the economy of the Common Market ${ }^{13}$ make necessary a consistent understanding and use of antitrust principles within the national legal systems. The beginnings of a development in this direction can be seen in the Federal Republic of Germany, where the well-supported activities of the Federal Cartel Office and the civil courts' engagement in considerable private litigation have enmeshed antitrust law into the legal system. To a lesser extent this is true in France. Efforts to maintain the Common Market in its original liberal-economic framework can only be successful with support "from below."13a It is obvious that these developments would in the long run be of great assistance to the Commission in the execution of its functions.

PREEMPTION OF JURISDICTION BY THE COMMISSION

The pattern of dual enforcement of the Community antitrust laws stems from Regulation No. 17 of the Council of Ministers. ${ }^{14}$ Article 9 thereof categorizes the division of powers between state and Community on the basis of the ain of the proceeding involved: ${ }^{15}$ whether to establish

${ }^{11}$ See Günther, Harmonisierung der Wettbeverbsbedingungen-Voraussetzung der Wirtschafts union, 19 BETREESS-BERATER 3 (1964); Linssen, The Antitrust Rules of the European Economic Community, 18 Record of N.Y.C.B.A. 289 (1963).

12 See, e.g., Bebr, Judicial Control of tae European Comanunities 210 (1962); see generally Deutsch, Supranational Organization in the 1960's, I J. Comaron Mrt. STUdres 212, 215 (1963).

13 Monopolies are subject only to a control for "abuse of dominant positions"; Treaty Establishing the European Economic Community, March 25, 1957, art. 86, 298 U.N.T.S. 11 (1958) [hereinafter cited as Treaty]. Mergers are not subject to any control. The Commission has requested a major study of this problem by outside experts, presumably with a view to recommending legislative correction of this situation. See its announcement in 6 BuLx. E.E.C. 49-50 (No. 9/10, Sept./Oct. 1963); Cosmo's of the EEC, Mearorandum Concerning the Action Programane $\llbracket 205$ (1963). See Roberts, The Concept of the Dominant Firm, 13 CARTEL 142, 155-57 (1963).

${ }^{132}$ See Günther, Die ordnungspolitischen Grundlagen des EWG-Vertrages, 13 WoW 191 (1963).

14 Regulation No. 17, 5 J.O.C.E. 204 (Feb. 21, 1962), as amended to postpone deadlines for notification, Regulation No. 59, id. at 1655 (July 7, 1962). An English version was published in 5 Burx. E.E.C. (Supp. No. 2, Feb. 1962).

15 "(1) Subject to review of its decision by the Court of Justice, the Conimission shall bave sole competence to declare Article 85, paragrapli 1, inapplicable pursuant to Article 85, paragrapl 3, of the Treaty.

"(2) The Commission shall have competence to apply Article 85, paragraph 1, and Article 86 of the Treaty, even if the time limits for notification laid down in Article 5, paragraph 1, and Article 7, paragrapl 2, have not expired." Regulation No. 17, arts. 9(1), 9(2). For article 9(3), see text accompanying note 22 infra. 
a violation of article $85(1),{ }^{16}$ or to procure an exemption from that provision under article $85(3) .{ }^{17}$ An exemption may only be granted by the Commission. Once granted, no national authority, be it court or cartel office, may prefer or pass upon a charge that article $85(1)$ was violated by the same agreement. ${ }^{18}$ While the Commission's exemptions are limited in time, ${ }^{10}$ they are renewable. ${ }^{20}$ This matter of continuing immumity is not a simple one. "Changed circumstances," which presumably means such environmental matters as a higher level of concentration in the industry and more aggressive cartelizing behavior in other areas by the firms involved, ${ }^{21}$ permit the Commission to cancel or refuse to renew an exemption. For similar reasons it might be desirable that national authorities also have the power to bring article 85 (1) charges against parties to previously exempted arrangeinents. Article $8(3)$ of Regulation No. 17, however, grants only to the Commission this limited power to revoke exemptions. By not specifying the right of national agencies to act, the regulation appears to preclude their exercise of jurisdiction in this regard.

16 "Incompatible with the Common Market and prohibited are all agreements between enterprises, all decisions of associations of enterprises and all concerted practices which are apt to affect the commerce between Member States and which have as their object or effect the prevention, restriction or adulteration [more commonly "distortion"] of competition within the Common Market, and especially those which consist in:

(a) fixing directly or indirectly the purchase or sales prices or other conditions of transacting business;

(b) limiting or controlling the production, distribution, technical development or investment;

(c) dividing the markets or sources of supply;

(d) applying unequal conditions for equivalent goods or services vis-à-vis other contracting parties, thereby inflicting upon them a competitive disadvantage;

(e) conditioning the conclusion of contracts upon the acceptance by the other contracting parties of additional goods or services, whicb, neither by their nature nor by commercial usage, have any connection with the object of these contracts." Treaty, art. 85(1). (TransIation from Riesenfeld, The Protection of Competition, in 2 STELN \& Nicholson, AMrericaN Enterprise in the European Common Market: A Legal Profile 197, 200 (1960).

17 "However, the provisions of paragraph (1) may be declared mapplicable to: any agreement or category of agreements between enterprises, any decision or category of decisions of associations of enterprises, and any concerted practices or category of concerted practices, which contribute to the inprovement of the production or distribution of commodities or to the promotion of technological or economic progress, while reserving an appropriate share of the resulting profit to the consumers and without:

(a) imposing on the enterprises mvolved any restrictions not indispensable for the attainment of these objectives, or

(b) enabling such enterprises to eliminate competition in respect of a substantial portion of the commodities involved." Treaty, art. 85(3). (Translation from Riesenfeld, supra note 16 , at 200-01.)

18 This is the inference from article $9(1)$ of Regulation No. 17, set forth at note 15 supra.

19 Regulation No. 17, art. 8(1).

20 Id. at art. 8(2).

21 But see Lazerow, Price Discrimination and the Treaty of Rome: The Jurisdictional Elements, 23 FED. B.J. 147 (1963). 
Proceedings involving an original violation of article 85(1) come before national courts or agencies subject to a different kind of Commission exclusivity. Article $9(3)^{22}$ provides that, "As long as the Commission has not initiated any proceeding ... the authorities of the Member States shall remain competent to apply Article 85 , paragraph $1 \ldots$ in accordance with Article 88 of the Treaty, even if the time-limits for notification laid down in Article 5, paragraph 1, and Article 7 have not expired." After the Commission has initiated these proceedings it is arguable that national action is preempted. To what extent is this result justified? Three relevant issues arise from the language of article 9(3) and require exploration: the definition of "authorities"; the scope of "shall remain competent"; and the definition of "proceedings initiated by the Commission."

\section{A. National Authorities}

Are national courts included within the term "authorities" and thus subject to losing jurisdiction over cases involving article 85(1) once the Commission chooses to act? Conflicting opinions abound. ${ }^{23}$ Some commentators have relied upon the analogy offered by article 88 of the Treaty, ${ }^{24}$ where the term ("autorités," "Behörden," "autoritá," "autoriteiten") must be read to include courts. ${ }^{25}$ From this, they have suggested that courts are subject to the jurisdictional restraints imposed by article 9(3) of the regulation as well. ${ }^{26}$ The analogy is not compelling. Since article 88 is a grant of power to national authorities to apply national law as well as the Treaty provisions, it cannot very easily be read to limit that grant to administrative agencies only, when many of the Member States have no such agencies. Perhaps the fact that article 9(3) speaks of the authorities as continuing to exercise their powers "in accordance with Article 88" is another makeweight argument for the same broad definition of "authorities,"

22 See text accompanying note 15 supra.

${ }^{23}$ See Samkalden, De Bevoegdheidsverdeling in de eerste kartelverordening van de EE.C. (pt. 2), 10 SoctaAi Economissche Wetgeving [hereinafter cited as Soc. Ec. Wet.] 273 (1962); Schbeder, Die Anwendung der Artikel 85 und 86 des EWG-Vertrages nach dem Erlass der ersten Durchfiihrungsverordnutng, 17 BETRIEBS-BERATER 305 (1962); see also WOHLFARTH, EVERLING,

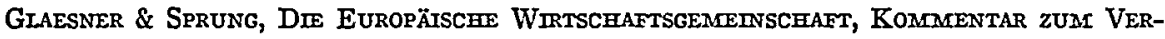
TRAG 257 (1960).

24 "Until the entering into force of the provisions issued in application of Article 87, the authorities of the Member States shall pass on the permissibility of agreements, decisions and concerted actions as well as on the abusive exploitation of a dominant position in the Common Market in conformity with the law of their own countries and with the provisions of Articles 85, especially paragraph (3), and 86." Treaty, art. 88. (Author's translation.)

25 This view is explained by Schumacher, Die Durchführung der Artikel 85 und 86 des Rom-Vertrages, 12 WuW 475, 483 (1962).

26 Ibid.; see also Mezger, Communautés Eutropéennes, 52 REvUE CRITIQUE DE DROIT INTERNationar Privé 399, 408, 412 (1963). 
but this argument, too, seems unpersuasive. That reference was made for purposes not relevant to the definition. ${ }^{27}$ On the other hand, an attempt to free courts from the limiting effects of the provision on the basis of some rather cryptic "legislative history" that traces the evolution of the phrase through the consulting European Parliament is equally unpersuasive. ${ }^{28}$

The answer probably can be discovered only by looking at the respective functions of courts and agencies within each Member State, and in particular by reviewing whether the private litigation role of the courts will be arbitrarily and unnecessarily compromised if they are included in the phrase. This, or a similar approach, has been attempted by several commentators, and in general they favor a narrow reading that frees courts from the preemptive effect of article $9(3) .{ }^{29}$ This result, however, is complicated by the varying roles the courts play as antitrust enforcement bodies in the different jurisdictions. In France, for example, the cartel agency, the Commission des Ententes et des Positions Dominantes, is merely an advisory arm of the Mimister of Economics. ${ }^{30}$ There, it has been suggested the courts must be classified as "authorities" and bound by article $9(3)$, because of their administrative role in exercising these enforcement responsibilities. ${ }^{31}$ The point of view of the Commission is similar.

27 Article 88 grants power to national authorities to apply articles 85 and 86 "in harmony with their own law," as long as the Council regulations called for in article 87 (e.g., Regulation No. 17) have not heen enacted. See note 24 supra. Article 9(3) of Regulation No. 17 perpetuates national jurisdiction, however, pending Commission action in each given case. Its reference to article 88 is more to the "in harmony with national law" clause than to a cut-off, in time, of national competence to apply articles 85 and 86. Another Council regulation may effect this end; Regulation No. 17 has not. See BEBR, op. cit. sicpra note 12, at 210 "Sk." [Samkalden], Het arrest van Het Hof van Justitie der Europese gemeenschappen van 6 April 1962 in de zaak 13-61, (Bosch), 10 Soc. Ec. WET. 216, 220-21 (1962).

In any event, article 88 is concerned with the interim applicability of national laws, not primarily of Community law. See the conclusions of Advocate General Lagrange in Case No. 13/61, Kledingverkoopbedrijf de Geus en Uitdenbogerd v. Robert Bosch GmbH \& N.V. Maatschappij tot voortzetting van de zaken der Firma Willem van Rijn, [heremafter cited as Boscri] 8 Rec. de la jurisprudence de la Cour [heremafter cited as Rec. Cour] 97-142 (1962).

28 van den Heuvel, Civil Law Consequences of Violation of the Antitrust Provisions of the Rome Treaty, 12 Aar. J. Comp. L. 172, 179 \& n.17 (1963). The earher phrasing rehed upon by van den Heuvel actually gave the Commission exclusive power to apply article $85(1)$ as well as article $85(3)$, shutting out therefrom judicial as well as administrative authorities. See article 7(1) of the draft regulation approved hy the European Parliament, 4 J.O.C.E. 1409, 1413 (Nov. 15, 1961). The change from this to the present phrasing proves nothing. Compare the conclusions of Advocate General Lagrange in the Bosch case, supra note 27, at 141 (which in this respect were not adopted by the Court of Justice).

29 For a review of the hiterature and for this general conclusion, see Deringer, Kommentar, 13 WvW 363-66 (1963) (annots. 14-22).

30 For a discussion of the role of this body, see Riesenfeld, The Legal Protection of Competition in France, 48 CALTF. L. REv. 574 (1960). The Commission's name and functions were expanded hy the Law of July 2, 1963, No. 63-628, [1963] Journal Officiel 5915 (Fr.) ; 46 BuLLETIN LÉGTSLATTF DALLOZ pt. a, 326 (1963).

31 See Deringer, Kommentar, 13 WoW 365 (1963) (annot. 9) ; but cf. Goldstein, supra note 8 . 
In its December 21 Announcement creating mass negative attestations for certain agreements, it states that these declarations do not bind national authorities, "especially the courts." 32 Finally, this restrictive view has been accepted, though without discussion, by the few national decisions that have been entangled in jurisdictional disputes, ${ }^{33}$ but these were French cases and their results are compatible with the more conservative solution favored by most writers. In my opinion, the problein is less one of defining the administrative functions of the courts than of safeguarding their civil functions. Thus, it is entirely conceivable that a court might be an "authority" for some purposes and not for others, and thus subject to the preemptive effect of article $9(3)$ in part only. Eventually, it seems clear, the Court of Justice will have to resolve the matter. ${ }^{34}$

\section{B. "Shall Remain Competent"}

A functional approach can also be used to resolve the second issue under discussion: whether article $9(3)$ merely precludes new proceedings or also cuts short those already commenced. This problem is primarily one of policy in the sense that all four official versions of article 9(3) may be read as meaning that the national authorities' competence to apply Community law, if exercised in a particular case, continues despite later initiation of proceedings by the Commission. On the other hand, the opposite reading is equally defensible. If courts in the exercise of their private litigation functions are not "authorities," the issue is not important, for the only difficult problem is halting private litigation in midstream, as the French courts have felt obliged to do. ${ }^{35}$ If only administrative enforcement is involved, including appellate review thereof, suspension in favor of later initiated Commission proceedings would probably be acceptable to national policy makers. If, on the other hand, convenience and logic dictate that courts be included in the definition of "authorities," then the more awkward results of that definition could be obviated by the functional approach suggested in the discussion of "national authorities."

\section{Initiation of Proceedings}

At the present time no definition of "initiation of proceedings" has been formulated by the Commission or the Court, ${ }^{36}$ though this could easily have

32 Announcement of December 21, 1962, 5 J.O.C.E. 2922 (Dec. 24, 1962) (appended to Regulation 153). English translations may be found in Ladas, The Deadline of January 1, 1964 for Industrial Property Agreements, 8 ANTitrust Bulc. 85 (1963); Forrow, Developments Under the Common Market Antitrust Regulations, 18 Bus. LAw. 791, 802 (1963). See note 38 infra.

33 See text accompanying notes 49-56 infra.

34 So much was recommended by Schumacher, stupra note 25 , at 483 .

35 See text accompanying notes $49-56$ infra.

36 For a discussion of this problem, see Deringer, Kommentar, 13 WuW 363-64 (1963) (annots. 14-17) ; Samkalden, supra note 23, at 275-76. 
been accomplished by a Commission regulation or, even if without binding effect, by inclusion in its Practical Guide. ${ }^{37}$ The "proceedings" can be either for a negative attestation, ${ }^{38}$ which requires that one of the contracting parties first submit an application, or for an exemption with its preceding and analogous notification procedure. In neither case would the Commission be acting on its own motion. In addition, of course, the proceedings might be to establish a violation of article 85(1), which could be initiated by third party complaint or by the Commission. Here a charge or complaint by the Commission in all probability amounts to the initiation of proceedings; the private complaint probably does not, unless and until the Commission actively investigates the complaint. The docketing of the charge, presumably involving a staff investigation, might qualify were it not that many complaints undoubtedly will not be pressed due to lack of merit or public concern. ${ }^{39}$

Exemption applications are distinguishable from proceedings to establish a violation of article $85(1)$, because of the possible retroactive nature of exemptions, a topic explored more fully later. With these as well as with negative attestations, receipt and acknowledgment of applications are even less likely to qualify as the initiation of a proceeding, if only because of the practical absurdity of foreclosing national consideration of some 35,000 agreements-the number already submitted and on which the Commission may be working for years. ${ }^{40}$ The initiation of consultative review with national cartel authorities, however, required for both cases by article 10 of the regulation, would definitely constitute "initiation." The dividing point may be the written or published notice of the hearing, which the new Commission Regulation No. 63/99 of July 25, 1963 requires on applications for exemptions and negative attestations (as well as on complaints) and which must occur prior to consultation with the national cartel office. ${ }^{41}$ In general, this is the kind of issue on which a determination by the Com-

37 Service de Presse et D'Information des Comarunautís Européennes, Guide Pratique Concernant Les Articles 85 et 86 Du Tratté Instituant La C.E.E. Et Leurs RìgteMIENTS D'Application (1962), English version reprinted in CCH Common MKT. Rep. I| 2701 (1963).

38 "At the request of the enterprises or associations of enterprises concerned, the Commission may find that, according to the information it has obtained, there are, under Article 85, paragraph 1, or Article 86 of the Treaty, no grounds for it to intervene with respect of an agreement, decision or practice." Regulation No. 17, art. 2 .

39 Pursuant to article 3 of Regulation No. 17, the Commission may move ex officio or upon request of a Member State, or of natural or legal persons or groups "who show a justified interest." It may be, however, that third parties may be able to compel the Commission to bring proccedings. See the excellent study by Steindorff, Das Antragsrecht in EWG-Kartellverfahren uthd seine prozessuale Durchsetzung, 9 AUSSENWIRTSCHAFTSDENST DES BETREEusBERATERS [hercinafter cited as AWD] 353 (1963).

${ }^{40}$ See Linssen, supra note 11 , at 299.

416 J.O.C.E. 2268 (Aug. 20, 1963). It is based upon article 19 of Regulation No. 17. 
mission would probably be treated with respect by the Court of Justice and national tribunals.

This discussion suggests that national courts may retain considerable freedom to continue pending litigation even if they are held to be "national authorities" and subject to article $9(3)$. If "initiation" is conservatively defined, ${ }^{32}$ only Commission-initiated proceedings against agreements for violation of article 85(1) would qualify as "particular initiated proceedings" from the outset. Commission action on private third party complaints, and upon applications for exemption or negative attestation (both reaching it through notification) ordinarily, and certainly while the present backlog is being reduced, would not reacl the status of "initiated proceedings" for some time after coinplaint or notification occurs. ${ }^{43}$ In national litigation, however, be it civil or administrative, only such third party complaints or participants' submissions will trigger action by the Commission. In the normal case this will allow the national tribunal or agency considerable time to reach its own decision and rule on the agreement or on the parties' rights to enforce or disregard the particular restrictive arrangement. It is of course possible that a state agency proceeding could be followed, indeed superseded, in unseeming haste by an official complaint of the Commission against the same arrangement, but the liaison between national agencies and the Commission will probably be good enough to avoid this kind of gratuitous clash. ${ }^{44}$

From this review it would appear that all national authorities should be free to decide issues arising in both admimistrative proceedings and civil actions, whether or not the Commission has been notified of the agreements involved ${ }^{45}$ so long as it has not proceeded further. In addition, courts, as distinguished from cartel agencies, may well be free to continue an existing civil action in the face of the Commission's active consideration of the same case. In many instances this may seem absurd, since any decision against the agreenent would probably only retain its effectiveness until the date of the Commission's later decision to hold the agreement legal or to grant it an exemption. ${ }^{46}$ Practically, however, this limited power may

\footnotetext{
42 As suggested in text accompanying notes 36-40 supra.

43 This tentative conclusion, however, is subject to the discussion of article $9(3)$ in text accompanying notes $66-70$ infra.

44 See Regulation No. 17, arts. 10, 11, 13.

45 Again, this is subject to the qualifications in text accounpanying notes 66-70 infra. This cross-reference cannot be avoided, since there is no way to consider article $85(1)$ proceedings in the abstract and apart from the 85 (3) exemption process. The notification of the Commission of thousands of agreements, in the hope of obtaining exemptions therefor, indicates that the disturbing effects of the Commission's exclusive jurisdiction over these exemption apphications under article $9(1)$ of the regulation cannot be ignored even at this point.

46 See the discussion in text accompanying notes 57-62 infra, for the problems created by the retroactive nature of some exemptions, pursuant to article $6(2)$ of Regulation No. 17.
} 
cause the Commission to reconsider a contrary opinion, for reasons of comity if nothing else. ${ }^{4 \pi}$ In any event, as will be explained, ${ }^{48}$ the consequences of a later and contradictory Commission decision are not overly serious.

More serious, on the contrary, are the consequences of undue deference by national courts to this specter of potential Commission edicts. Two recent French cases illustrate the unsatisfactory results of this deference. In Société U.N.E.F. v. Etablissements Consten, ${ }^{49}$ respondent's charge of unfair competition under French law against the complainant was countered by the latter's claim that respondent's agreement with the German Grundig firm for an exclusive franchise for certain products in France violated article 85 of the Rome Treaty. The lower court had found for respondent: ${ }^{50}$ It held the agreement valid and for good measure purported to grant an article 85(3) exemption, though its decision of May 21, 1962 was after the effective date of Regulation No. 17. Complainant appealed and at the same time requested the Commission to find the agreement in violation of article 85(1). The Cour d'Appel of Paris held that it could not now consider the case, smce the Commission had meanwhile obtained "exclusive" jurisdiction to declare the contract void. The court decided that certain letters from the Commission, both to the complainant advising that its charge was being considered and to the French cartel authorities bringing them into an article 10 consultation, established its "active consideration" of the complaint; i.e., the Commission had initiated particular proceedings within the meaning of article $9 .^{51}$ The court then considered the potential effects of any possible article 85(3) exemption, the grant of

47 There is also the argument that a prohibited agreement, being void under articlc $85(2)$ of the Treaty, cannot be the subject of a negative attestation; for the dubious validity of the analogous argument in the case of an article $85(3)$ exemption, sec text accompanying notcs 100-101 infra.

Equally, the Commission probably is not bound by a prior national decision that an agrecment does not violate article $85(1)$ when it decides to hold otherwise.

48 See text accompanying notes 168-77 infra.

49 Soc. Umion nationale des écononies familiales v. Consten, Cour d'Appel de Paris, Jan. 26, 1963, [1963] Dalloz Jurisprudence 189 (Fr.) (note Robert) ; [1963] Semainc Juridique 13103 (Fr.) (note Desangles, Advocate General); case reprinted in 52 Revur Critique de Droit Internationat PrVÉ 406 (1963). English translations of the case appear in 90 Journat DU Droit International 729 (1963), and CCH Comamon MKT. Rep. П 8009 (1963).

50 The lower court opinion, though not separately reported, is sumınarized in the Cour d'Appel's opinion.

51 Defendant made its complaint to the Commission on March 6, 1962, and was advised on March 28 that the charge had been registered as of March 13. On June 15, 1962, the Commission advised defendant that "the procedures envisaged by Regulation 17 had been initiated" and the French authorities so advised. In fact, this was done by letter of the same date to the French Ministry of Commerce, pursuant to article 10 of the Regulation, which requires consultation with the national cartel authorities when notifications or complaints of illegality are received. The term, "la procédure prévue au règlement no. 17 avait été engagée" is a term of 
which was a matter exclusively for the Commission. The notification deadline of February 1, 1963 had not yet been reached, and thus an exemption was still possible. If granted by the Commission it might be retroactive even beyond the date of the possible notification and would be binding upon the national courts. For both reasons the Cour d'Appel refused to consider the applicability of article 85 and suspended all proceedings in the case until the Commission had acted..$^{52}$

In another significant case, Société Pierre Rivière et Cie. v. Société nouvelle de produits alimentaires "La Maison du whisky,",53 the Tribunal de Commerce of Seine held valid certain exclusive dealing agreements, of which the Commission had been notified by plaintiff, unless the Commission invalidated them. At the same time, however, the Tribunal invited defendant to evade this holding by prohibiting the latter's sale of the same products only so long as it had neither intervened in the notification proceedings as a third party or complained directly to the Commission against the agreements. Although defendant had not yet followed either course, the Tribunal further suspended all proceedings on plaintiff's additional demand for penalties for the already elapsed period of unfair competition. The decision has already been justly criticized ${ }^{54}$ though even under French law alone these arrangements might not have met any better fate than resulted from their de facto unenforceability due to the suspension of judgment. ${ }^{55}$ Nevertheless, this excessive show of deference to a mere complaint or notification has business consequences that are doubly unfortunate because the court's refusal to proceed is so unnecessary. ${ }^{56}$

art, since article 9(3) leaves the state authorities free to apply article 85 so long as the Commission has not initiated such proceedings; in the French original of this article, "engager" is the term so translated.

62 This was requested by the defendant in the municipal case, complainant before the Commission. The proceedings were suspended until a "definitive decision" is rendered by the Commission on defendant's complaint to it.

53 Société Pierre Rivière et Cie. v. Société nouvelle de produits alimentaires "La Maison du whisky," Tribunal de Commerce de la Seine, March 5, 1963, [1963] Dalloz Jurisprudence 367 (Fr.) (note Robert).

54 See the note by Robert, supra note 53 , at 369.

55 In Nicolas et Société Brandt, Cour d'Appel de Amiens, May 9, 1963, [1963] Semaine Juridique 13222 (Fr.), the court held illegal under French law an exclusive dealing arrangenent despite its submission to the Commission, and in the face of a renand of the case from the Cour de Cassation, which "reversed" a prior holding of illegality. See Riesenfeld, supra note 2, at 833-35, for discussion and citations to the earlier case. Compare, however, two recent German decisions: Oberlandesgericht München, May 30, 1963 ("Foto-kameras"), in WoW/E OLG 556, 13 WoW 626 (1963); Bundesgerichtshof (Kartellsenat), June 14, 1963 ("Trockenrasierer"), in 17 NEUE JURISTISCEE WOCHENSCHRIFT [hereinafter cited as NJW] 152 (1964).

56 One German court, too, has succumbed to the numbing effects of article 9 (1). Kammergericht [Berlin], May 4, 1962 ("Fensterglas III") in WoW/E OLG 469, 12 WoW 697 (1962). There a group of producers appealed from a refusal by the Federal Cartel Office to authorize a rebate cartel under article 3 of the German Cartel Law (see note 128 infra). Ground for 
II

TEMPORAI JURISDICTIONAL CONFLICTS AND ARTICLE 85(3) EXEMPTTONS

With this discussion of Consten and Rivière the more difficult jurisdictional conflicts are reached. That the Commission by initiating proceedings may deprive an agency or possibly even a court of its substantive jurisdiction to apply article $85(1)$ is not as important as the result of exemption proceedings the Commission may entertain. This concerns five types of restrictive practices:

(1) Old agreements, of which the Commission must have been notified by now if an exemption is even to be considered; ${ }^{57}$

(2) Old agreements that fall within article 4(2), of which the Commission need not yet be notified, as long as it is notified before exemption is requested; ${ }^{58}$

(3) Old agreements, also non-notifiable under article 4(2), but for some more formal reason not exemptable under the article 85(3) criteria, which may be modified and then submitted to the Commission by January 1,1967 for possible exemption; ${ }^{59}$

(4) "New," notifiable agreements; ${ }^{60}$ and

(5) New agreements, non-notifiable under article 4(2).

Of these five types, the exemptions that may be granted for the first three can be made retroactive for various periods, at least to the date of notification, ${ }^{61}$ and probably back to March 13, 1962, the effective date of Regu-

refusal was the failure of the cartel to count for rebate purposes purchases made from other EEC producers. The court agreed with the Cartel Office that this violated article 85, but held that the right of the producers to notify the Commission of the agreement and possibly obtain an exemption therefor, which if granted might be retroactive, precluded a denial of the authorization on that ground alone. The agreement, as the court admitted, was non-notifiable; therefore, the Cartel Office and this appellate court were both hindered, for the indefinite future, from applying article 85 to such a rebate cartel!

57 These are agreements in existence before March 13, 1962, the effective date of Regulation No. 17. Also included here are notifiable agreements whose clearly illegal provisions were abrogated by the parties, who then submitted them by February 1, 1963, pursuant to article 7(I) of Regulation No. 17.

58 Article 4, of course, concerns new agreements only. The old agreements nentioned in the text are in fact covered by article $5(2)$, which incorporates by reference the substantive provisions of article $4(2)$. Article $4(2)$ concerns "less dangerous" restrictive practices, submission of which has been excused for the indefinite future to avoid overloading the Commission's staff. For an analysis of these practices see, e.g., Becker, supra note 2 .

59 Regulation No. 17, art. 7(2), as modified to extend the deadline for the sulmmission of these agreements by Council Regulation 118/63, 6 J.O.C.E. 2696 (Nov. 7, 1963).

60 Regulation No. 17, art. 4(1).

61 Notifiable new agreements can be "retroactively" exempted only to the date of notification, article $6(1)$, but this limit does not apply to non-notifiable agreements or old notifialle agreements that were timely submitted. Article 6(2). Concerning the agreements described in note 58 supra, see article $7(1)$. 
lation No. 17. It appears, therefore, that the real problem, the basic reason why the Cour d'Appel in the Consten case refused jurisdiction after nothing more than a submission of the disputed agreement to the Commission, lies in the potential conflict between a national court's finding of a violation and the Commission's later but possibly retroactive exemption of the agreement. The national courts may feel barred from proceeding although the Commission has not begun to act; indeed, before notification, at least for the second, third, and fifth types of agreements. Furthermore, this inhibition may influence courts even if they are not "authorities," since the embarrassment is created by article $9(1)$ more than by $9(3)$; that is, by the Commission's exemption powers as much as by the preemptive nature of an "initiated proceeding." ${ }^{2}$

There is a tendency to resolve this difficult issue by accepting exclusive centralized enforcement without a full consideration of the alternatives ${ }^{63}$ Deringer, author of the most extensive commentary in this field, argues persuasively against lumping all courts in the phrase "authorities." ${ }^{64}$ Even he, however, reaches conclusions that, if valid, would have to be applied to courts as well as to his narrowly defined "authorities."

"In practice, the national authorities cannot exercise their jurisdiction:

(a) over any agreements for the period between notification and the decision of the Commission under art. 85(3), because for this period a retroactive exemption is always possible (Art. 6(1));

(b) over notifiable old agreements for the period to the end of the period for notification, because a timely notification is still possible and in this case the agreement can be retroactively exempted (Art. 6(2));

(c) over all non-notifiable old or new agreements, because here an exemption is possible from the date of Regulation No. 17, or at least from the date of the agreement (Art. 6(2)). ${ }^{265}$

Before any discussion as to the difficulty of applying these limits to the agencies only, an objection to these conclusions should be considered. This objection, recoguized but rejected by Dermger, ${ }^{66}$ is a somewhat technical one based upon the wording of article 9(3). His approach consciously reads out of the provision its last clause: “[Member States' authorities remain competent to apply articles $85(1)$ and 86$]$ even if the time limits for notification laid down in Article 5, paragraph 1, and Article 7 have not

62 See the conclusions of Advocate General Lagrange in Bosch, 8 Rec. Cour. 97, 141-42 (1962).

03 See, e.g., Graf, Der 31 Januar 1963-Wichtiger Stichtag für die Anmeldung von "Altkartellen" nach EWG-Kartellrecht, 18 BETRIEBS-BERATER 18 n.14 (1963),

64 Deringer, Kommentar, 13 WoW 364-66 (1963) (annots. 18-22).

65 Id. at 370 (annot. 34).

68 Id. at 370 (annot. 35). 
expired." Article 5(1)'s time limit governs type (1) agreements; ${ }^{07}$ article 7's, type (3). For both types, retroactive exemptions are foreseen, yet the regulation obviously also contemplates continued national jurisdiction. In fact, the same is probably true for type (2) agreements. Their analogue, type (3), is covered, so why not they? The failure of article $9(3)$ to refer to these non-notifiable agreements by name can be explained by the awkwardness of speaking of time limits for the submission of non-notifiable agreements. Moreover, it is not at all clear that actual notification ends national authorities' jurisdiction over the submitted agreements. Admittedly the clause points in that direction, given its use of "time limits for notification" rather than "despite notification" in the safeguarding proviso, but such a distinction would be pointless. If one assumes, as is clearly proper from the wording, that national jurisdiction over non-notifiable agreements survives, then it seems that the possibility of retroactive exemptions and their collision with earlier conflicting state decisions did not frighten the Council..$^{\text {s }}$ In addition, as has been explained, notification of the Commission may not be the same as the initiation of proceedings by it, ${ }^{69}$ so the basic preemptive aim of article $9(3)$ need not automatically attacl to agreements merely because the Commission has been notified of them. In that case, since there is no difference between already submitted and non-notifiable agreements, there would also be no reason why the safeguarding proviso could not be read to apply to national jurisdiction over both types of agreements. Indeed, this seems to be the view of the Court of Justice, which in the Bosch case specifically approved national jurisdiction over already submitted agreements. ${ }^{70}$

In any event, whatever the eventual result as to already submitted agreements, Deringer's effort to separate non-notifiable agreements is not persuasive in light of article 9(3)'s applicability to type (3) agreements, which are nothing more than non-notifiable agreements suffering from some formal defect. ${ }^{71}$ Thus, the reason why old agreements of which the Commission was timely notified (before February of 1963) are no longer subject to the continuing jurisdiction of national authorities cannot be found in the retroactivity of any exemption grantable to them; it lies, if at all, in the plain wording of article 9(3), and it does not appear to be there either.

67 See text accompanying note 57 supra; this type includes agreements described in that note.

68 See note 61 supra.

69 See text accompanying note 38 supra.

70 In Bosch, 8 Rec. Cour 97, 115 (1962), the Court of Justice states that under article 9(3) national authorities may apply article $85(1)$ to agreements of which the Commission bas been notified. Compare Deringer, Kommentar, 13 WoW 371 (1963) (annot. 36).

71 For a fuller explanation of these article $7(2)$ cases, see Buxbaum, supra note 9. 
It must be conceded that the potential conflict of national and Community decisions may well continue to inhibit national tribunals in judging agreements under article 85 . In the case of old agreements, reluctance will be particularly a result of the exemption problem. In general, these agreements either have been submitted, or are non-notifiable under article 4(2), or are patently illegal and will not be discovered by self-policing methods. As to these agreements, therefore, the problems are: (1) if they have been submitted, whether national authorities can continue to act as long as the Commission has not initiated proceedings in the particular case; ${ }^{72}$ and (2) if they are non-notifiable agreements, whether the national authorities $^{73}$ will feel barred from proceeding because of the retroactive exemption possibility. Since new notifiable agreements cannot be exempted retroactively, only the question of "initiated proceedings" need disturb the national authorities.

In fact, and unfortunately, new notifiable agreements will remain a source of trouble to both national and Community authorities; not because of "initiated proceeding" problems, but because of the uncertain time limit for their submission by way of notification. This uncertainty is caused because Regulation No. 17 does not specify time limits for either notification or application for exemption in the case of new agreements. An absolute cut-off date, such as exists for old agreements, would have been impossible; but apparently even a relative time limit, for example, " 6 months after execution," was thought infeasible. Thus, two possibilities remain. If old and new agreements are to be treated alike, which most likely is the Commission's aim, a relative time limit will have to be inferred. Whether Regulation No. 17 delegates this power to the Commission is highly debatable. The issue will probably have to be resolved by the Court of Justice unless made moot by another regulation of the Council of Ministers. The other alternative is to permit new agreements to be submitted to the Commission by way of notification at any time, and to grant exemptions upon application, even if the exemptions cannot be retroactive beyond the date of notification. It is doubtful that the Court of Justice would uphold this interpretation of Regulation No. 17 as appropriate under the Treaty articles. For the time being, this question of a notification deadline for new agreements remains unsettled..$^{74}$

Non-notifiable agreements, new or old, aggravate the comity problem and increase the likelihood that national authorities will defer to the Com-

72 See text accompanying notes 36-41 supra.

73 If too broadly defined, this would include courts.

74 Compare the flysheet to the section on Competition, CHH Common MKT. REP. $\llbracket 2000$ (1963): "All new agreements should, of course, be presently notified for exemption purposes." 
mission in the regulation of "interstate" cartels and restrictive practices. If the Commission is notified of these agreements, they can, in the Commission's discretion, be exempted with retroactive effect beyond the date of actual notification. They can, by definition, be submitted to the Commission at any time, without present time limit. ${ }^{75}$ Since this indefinitely extended retroactivity may also impinge upon prior decisions, the inhibtions which seized the Cour d'Appel in the Consten case ${ }^{76}$ can be a constant source of difficulty here too, even though article 9(3) would not be a bar to national proceedings. Moreover, because non-notifiable old agreements are, at the least, extremely likely to win an exemption, the incentive will be great to notify the Commission of them at once when litigation threatens. Nevertheless, these are not reasons for urging restraint on national authorities; here as before it seems more appropriate for the Commission not to push its exempting powers to their limit than for courts or agencies to pull back for fear of such an event. ${ }^{77}$

There remains the second, and in my opinion more important reason for rejecting the conclusion, necessarily applicable to courts, that the retroactive nature of exemptions prevents the exercise of jurisdiction at the national level. The embarrassing temporal conflicts that retroactive exemptions can create exist also in other situations, yet the "solution" that cuts down national powers in the exemption situations can not be applied in these other situations. It can not be applied to cases in which a negative attestation by the Commission might follow a prior and conflicting national decision, though this involves almost the identical issues. True, a Commission decision that an agreement does not even fall under article $85(1)$ is not by its terms retroactively effective, but it resembles an exemption decision so far as a prior national finding of nullity ${ }^{78}$ is concerned. The second holding is definitive. According to it, the agreement in question is not invalid. Nevertheless, a prior and for some time legally effective judicial or administrative decision had nullified the agreement, and that decision may well have engendered reliance that now proves detrimental, at least as detrimental as reliance upon any decision countermanded by an exemption would be.

Temporal conflicts of decisions within an imperfect federal structure by their nature create the kind of dilemma in which Regulation No. 17,

75 Regulation No. 17, art. 6(2). A time limit may, of course, be imposed at some future date; indeed, that is expected. Regulation No. 17, art. 22(1). No changes, loowever, are contemplated for the immediate future. 6 BuLx. E.E.C. 27 (No. 6, June 1963).

76 Note 49 supra.

77 See, for example, the lessons described in San Diego Building Trades Council v. Garmon, 359 U.S. 236 (1959).

78 This consequence is prescribed by article $85(2)$ of the Treaty. 
as implemented by the December Announcement, ${ }^{79}$ finds itself. The radical and only logically strict approach is to divest the national judicial and administrative structure of all power to apply federal law. ${ }^{80}$ This the regulation has not done, except for article 85(3) exemptions, nor is it likely that this will be done in the near future. As Bebr said in 1962: "An exclusive jurisdiction of the Community in applying the Community rules governing competition is at the moment unrealistic. Such a solution would be feasible only in a well integrated political Commumity in which the Community organs enjoy strong political support. With fragile political support it is difficult, if not impossible, for the Community to pursue such a policy independently." ${ }^{81}$ His caution is if anything even more appropriate today. He suggests a division of powers with final decision reserved to the Community. ${ }^{82}$ Although such a proposal is commendable in theory, in practice it still involves uncertainty as to the legitimacy of business conduct, an uncertainty far more irritating than that inhering in the vagueness of the antitrust proscriptions themselves, of which so much has been made. ${ }^{83}$

79 Note 32 supra.

${ }^{80}$ In essence, this is the argument of Catalano, Rapports Entre Les Règles de Concurrence Etablies Par Le Traité CEE Et Les Législations Des Etats Membres, 15 Revue Internationad DE Droit CoMrapé 269 (1963). This position, presented at a meeting of the Federation internationale de droit européen in Brussels in October of 1962, was not accepted by the special committee on antitrust laws of that association, although it received solne support. $C f$. the resolution there adopted. $I d$. at 298.

81 Bebr, Judictal Control of the European Conmunities 210 (1962).

82 Ibid. See also Weiser, Antitrust Policy and Industrial Property in the European Economic Community, 38 N.Y.U.L. REv. 496, 521 (1963).

83 See note 56 supra.

Some examples may help to clarify the general argument above, though these are subject to the discussion in the text accompanying notes 168-76 infra, concerning the bearable nature of these collisions.

(1) A French manufacturer distributes its products through exclusive territorial franchises, several regional ones to each country, and includes in them prohibitions on exports to other nations as well as to other regions of that same state. A case like Consten arises, but at a time when the agreements can no longer be submitted for exemption. The franchised distributor wims a judgment that the agreement is vahd under article 85 , a judgment the local French court is empowered to render under article $9(3)$ of the regulation. Later the manufacturer applies for negative attestations for all other agreements, or the Commission proceeds against him and decides the agreements violate article 85 . What is the status of the first agreement earlier sued on? What are the riglts of the manufacturer who extended this kind of distribution to other areas in France in reliance upon the national decision of validity?

(2) A German patentee grants several territorial licenses within the Federal Republic, each containing a prohibition on foreign inanufacture and sale, a prohibition affecting commerce among the Member States. One of the German licensees complains to the Federal Cartel Office that the agreement it had been forced to execute violates article 85 , and wins a judgment nullifying the license. The patentee now requests the Commission to grant a negative attestation for all of its hicenses, and is successful. What are the original parties' new legal positions? Is their agreement still in effect? If the Commission's decision does not resuscitate that particular license, what are the rights of other erstwhile licensees which "cancelled" their agreements in reliance upon the decision of the Federal Cartel Office? 
RESOLUTION OF CONFLICTS THROUGH ARTICLE 177 OF THE TREATY

At this impasse, it becomes necessary to examine article 177 of the Treaty and to consider the often expressed opinion that by its use the Court of Justice can resolve these temporal conflicts between national and Community decisions..$^{84}$ Briefly, the article permits and in some instances requires the national tribunal to submit to the Court of Justice issues involving the interpretation of the Treaty or of Community acts that have arisen in litigation before that tribunal..$^{85}$ Courts of last resort are required to do so $;^{86}$ all other civil and administrative tribunals are permitted to use the procedure. For some purposes the article has already received a broad reading. The Court of Justice has recognized that it is not feasible to limit it to abstract interpretations and has used it to decide the applicability of Treaty provisions to at least generalized versions of the facts involved in the mumcipal litigation that occasioned the request. ${ }^{87}$ An embryonic doctrine of precedent has even been lesitantly suggested, whereby a national court may be spared the task of submitting every question of Treaty interpretation if the question has previously been answered by the Court of Justice in essentially the same context. ${ }^{88}$

Any effective use of article 177 for resolving conflicts presumes both that the procedure will be used consistently and that Court of Justice de-

84 See, e.g., Suetens, Prejudiciële Vragen In Het E.E.G.-en E.G.A.-Recht, 26 REcutsKuNDIG WEEKBLAD col. 1913, 1923-24 (1963). See also authorities cited note 85 infra.

85 See generally Knopp, Über die Pficht deutscher Gerichte zur Vorlage von Aislegunngsfragen an den Gerichtshof der Eurropäischen Gemeinschaften nach Art. 177 des EWG-Vertrages, 16 JURISTENzeitung 305 (1961); Pepys, $L$ 'Article 177 dat Traité de Rome et les jurisdictionss frangaises (pt. 1), 52 Revue Critique de Droit Internattonal Privé 475 (1963); Ehle, Vorlage an den Europäischen Gerichtshof gemäss Art. 177 EWG-Vertrag, 16 NJW 933 (1963). As to judicial review under article 177 and Court of Justice procedure under article 20 of its statute, see respectively, BEBR, op. cit. supra note 81, at 184-215; vAN REEPHINGEN AND OrIanne, la Procédure devant la Cour de Justice des Communautís Européenne (1961).

86 The definition of a court of last resort, from which no "normal" appeal is possible, is a matter of some difficulty. See, e.g., Lagrange, Les actions en justice dans le régime des Communautés européennes, 10 Soc. Ec. WET. 100 (1962); Bebr, The Relationship Between Community Law and the Law of the Member States, 11 INT'I \& CoMrP. L.Q. (Supp. No. 4) 1, 10 (1962).

87 Case No. 26/62 N.V. Algeunene Transport- en Expeditié Onderneming van Gend \& Loos t. Nederlandse Administratie der Belastingen [hereinafter cited as vaN GEND \& Loos], 9 Rec. Cour 1 (1963). (English translation by Riesenfeld, in 2 INT. Leg. Mat. 505 (1963).) See Riesenfeld \& Buxbaum, N.V. Algemene Transport- en Expeditie Onderneming Van Gend \& Loos c. Administration Fiscale Neérlandaise: A Pioneering Decision of the Court of Justice of the European Communities, 58 AMr. J. INT'L L. 152 (1964).

88 Case Nos. 28-30/62 Da Costa, Jacob Meijer N.V., Hoechst-Holland N.V. t. Nederlandse Administratie der Belastingen, 9 Rec. Cour 63 (1963). (English translation in CCH Conomon Mrt. Rep. If 8010 (1963). See 6 BuLL. E.E.C. 56 (No. 5, May 1963); "Sk." [Samkalden], Comment, 11 Soc. Ec. WEr. 227 (1963). 
cisions will bind national and Community organs in a federal sense. Conversely, the inability to obtain such completely binding decisions would necessarily mean either that the national courts abstain entirely from hearing these cases or that the parties thereto would be in no position to complain of later inconsistent Commission acts. In other words, when parties to the national proceeding do not obtain an article 177 certification, the Commission would remain free to embark upon a conflicting course at least in similar cases between other parties, if not even in the same case. ${ }^{39}$ Prejudicial decisions ${ }^{90}$ under article 177 , it is argued, could perhaps bind the Commission in a similar fashion as it is bound on direct appeal from its own decisions against particular agreements. ${ }^{91}$ This would eliminate at one stroke the problem of subsequent Commission action in conflict with earlier decisions of the national courts. The Commission has the right to participate in article 177 proceedings before the Court of Justice and thus can see to it that no decisions are made without its advice to the Court.92 In that event, might not these decisions bind the Commission, even if different cases involving the same type of agreement come before it? At least this would obviate the objection that the Commission might by conflicting action prejudice third parties that had relied upon prior national decisions to their detriment. ${ }^{93}$

Unfortunately, there are several weighty objections to this approach. To begin with the least important matter, the question of reliance, what of third parties that rely on the earlier national decisions but have no opportunity to influence the failure to proceed under article 177 ? Is their reliance upon the first decision to be ignored? It is arguable that reliance upon a decision not culminated by an article 177 submission is misguided as a matter of law, but what if that reliance is forced upon the outsiders by the operation of the prior decision-as when it prohibits the conduct in

80 While this can be compared to American doctrines of res judicata or collateral estoppel, it is intended as a very loose analogy. Any more rigorous parallel would be feasible only after a comparative review of the type made for the United States in Developments in the LawRes Judicata, 65 HaRv. L. REv. 818 (1952). See note 168 infra.

80 More accurately, pre-judicial or preliminary, for the term refers to decisions on matters preliminary to the chief issue to be decided in the case at luand.

o1 Treaty, art. 173. See BEBR, op. cit. supra note 81 , at $68-71$; Lenliofi, Jurisdictional Relationship Between the Court of the European Communities and the Courts of the Member States, 12 Burfalo L. REv. 296 (1963). For a critique of the limits of this review, see Buergenthal, The Private Appeal Against Illegal State Activities in the Eroropean Coal and ${ }^{\circ}$ Steel Community, 11 Axr. J. Conr. L. 325, 346 (1962).

92 Protocol on the Statute of the Court of Justice of the European Economic Community, article 20 , executed concurrently with the Treaty of Rome. See authorities cited note 85 stopra. The same privileges extend to the Meniber States and where relevant to the Council of Ministers. Protocol, art. 20.

${ }^{93}$ See also the suggestions in Suetens, supra note 84 , at cols. 1923-24. 
which they had been engaged ${ }^{94}$ Secondly, the Court and thus the Commission are to a considerable degree restricted by the submitting tribunal's formulation of the question to be answered..$^{95}$ The more the article 177 procedure becomes a vehicle for applying the Treaty or other Community enactments to particular fact situations, as it is bound to do, ${ }^{96}$ the more the Court of Justice's avowed deference to the form and limits of the questions submitted ${ }^{97}$ would prejudice the Commission, were it to lead to the establishment of binding precedent from inadequate or incorrect factual contexts.

This objection is related to a third serious objection to binding the Commission in this manner. The uniform progress of antitrust enforcement, ${ }^{98}$ indeed the very creation of substantive antitrust law, is to a great extent the function of the Commission. ${ }^{99}$ The suggested procedure would take the initiative and the opportunities for such development away from the Commission, forcing it to fight for its aims on battlefields not selected by it and often under tactical difficulties that it should avoid. Speaking of an analogous proposal, Bebr has warned: "If, however, the Commission were to function as a mere appropriate tribunal for reviewing the decisions of these [national] authorities, it would play a very passive role indeed. The Commission would, in such an instance, have no opportunity to develop a Community anti-cartel policy of its own .... The Commission would thus be dependent on the initiative of national authorities." ${ }^{100}$ The difficulty is compounded by the need to fit the exemption process into the suggested procedure. If a municipal decision which subsumes an article 177 certification binds the Commission, what becomes of the Commission's right to grant exemptions, even merely prospective ones, under article 9(3) of the regulation? An argument could be made for denying the right of exemption

94 That is not to concede that the problem of reliance on prior national decisions is so serious as to require completely centralized administration of article 85 ; see the discussion in text accompanying notes $168-77$ infra.

95 See Riesenfeld \& Buxbaum, supra note 87, at 155 .

96 vaN Gend \& Loos, 9 Rec. Cour 1 (1963); see Bebr, stupra note 86, at 14.

97 "The considerations which have been apt to guide a national tribunal in the choice of its questions as well as the relevance that it means to attribute thereto within the ambit of a litigation submitted to its judgment remain outside of the appraisal by the Court." vAN GEND \& Loos, supra note 96, as translated in 2 INT'L LEG. MAT. 505, 518 (1963).

${ }^{98}$ See Kronstein, The Significance of the Provisions Concerning Restraints of Competition Within the Total Perspective of the European Coal and Steel Community. Treaty and the European Economic Commumily Trealy, 1 CARTEL ANd MONOPOLY IN MOdera Law 131 (1961).

${ }^{99}$ See BEBr, op. cit. supra note 81, at 210-11; Schumacher, The Procedure for Giving Effect to Article 85 and 86 of the European Economic Community Treaty, 1 CARTEL AND MONOPOLY IN MODERN LAW 363, 374-75 (1961) (though in my opinion this pre-Regulation 17 discussion shightly overstates the need for centralized enforcement by focussing overly on international cartels).

$100 \mathrm{BEBR}$, op. cit. supra note 81, at 211 . 
to any agreement so invalidated; it is then, pursuant to article $85(2)$, a nullity, and cannot be revived by an exemption. This, however, contradicts the entire scheme of article 85(3), which provides exemptions for agreements that by definition otherwise violate $85(1)$, i.e., are a nullity. The fact that a preceding court judgment has confirmed the agreement's illegal and void status under $85(1)$ is hardly a ground for denying an exemption; the exemption presupposes that proscribed and void status. In addition, the Commission's right to distinguish between illegal agreements because of their economic or market context would thereby be denied. ${ }^{101}$

Finally, the article 177 procedure is not watertight enough to make its precedential effect on the Commission very useful. ${ }^{102}$ Lower courts and agencies need not submit Treaty issues to the Court of Justice, and their refusal to do so is not appealable nationally ${ }^{103}$ or to the Court or Commission. ${ }^{104}$ Even courts of last resort can avoid the ostensible duty of submittal by complying with it in form but not in substance. For example, the court may rule that the Treaty issue is not pertinent to the resolution of the dispute before it. ${ }^{105}$ Since article 177 speaks of "Treaty interpretation," the

101 Regulation No. 17, art. 8(3). See text accompanying notes 18-21 supra. On the other hand, the unsupported assertion that the Commission can always proceed no matter what the valid status of a prior national decision may entail, as in KIEEMAAN, DIE WETTBEwERBSREgeIN DER EWG 66 (1962), seems equally hard to justify. See the discussion in text accompanying notes 178-80 infra.

102 For examples see particularly Knopp, supra note 85; Hay, Federal Jurisdiction of the Common Market Court, 12 Amr. J. Comp. L. 20, 31-32 (1963).

103 This is not because a procedure might not be available, but because there is no duty of submission.

Concerning national appeal from the lower court's decision to certify a preliminary question to the Court of Justice under article 177, see especially Ehle, Sind Vorlagebeschlïsse gemäss Art. 177 Abs. 2 EWG-Vertrag beschwerdefähig?, 16 NJW 2202 (1963) (for German law). A brief coinparative analysis may be found in the Conclusions of Advocate General Lagrange in Boscr, 8 Rec. Cour 97, 127-33 (1962). In this very case such an appeal was inade, was pending while the Court of Justice considered the preliminary question, and was rejected by the Hoge Raad, May 18, 1962, in 37 NEDERLANDS JURIstenblad 463 (1962) (Neth.).

104 This is not only because there is no duty of submission, but also for lack of a procedure to effect such an appeal.

${ }^{105}$ A favorite way of doing this is to hold that "interstate commerce" is not involved. This occurred in Oberlandesgericht Düsseldorf, October 21, 1958 ("Sarotti' IV"), in WUW/E OLG 262, 9 WoW 298 (1959) (Ger.), where the court decided that since the price maintenance clause there involved could not affect interstate commerce, and so could not violate article 85 , there was no need to use article 17\%. This raises a nice question. Sport interpretations of "affect coinmerce between Member States" will seriously haunper the uniform development of substantive law on this basic point, see Ellis, Source Material for Article 85(1) of the E.E.C. Treaty, 32 Fordeanr L. REv. 247 (1963), yet the issue is less one of interpretation than of application of article 85 to particular fact situations; see note 106 infra. For an interesting reverse situation, see note 108 infra.

Such a national ruling is, of course, justifiable when the case can be disposed of as a violation of national law. This was the case in Nicolas et Société Brandt, May 9, 1963, Cour d'Appel de Amiens, [1963] Semaine Juridique 13222 (1963) (Fr.). Stricter national antitrust 
court can describe the problem as only one of application of the Treaty to particular facts; ${ }^{106}$ it can even invoke "precedent" and decide that the Court of Justice's position on the problem is known and so further interrogation of it would be useless. ${ }^{107}$ In short, not only does the court's form of submission bind the Court of Justice, ${ }^{108}$ but refusal to act at all can exist in many guises, all of them immune from challenge. ${ }^{109}$ Even an avowed refusal to submit an issue in violation of the Treaty would not necessarily, depending upon national law, impair the validity of the decision then rendered.

laws are applicable, even if article 85 might not be violated by such prohibited practices. Sec Schwartz, Deutscees Internationaces Kartelirecht 5-6 (1962); but see, Jeantet, Chronique de Droit Economique Européen, [1964] Semaine Juridique 1812, II 14. Less defensible is the reverse case, where national law is used to uphold the challenged practices and to preclude recourse under article 177; cf. Blume t. Van Praag, Oct. 25, 1962, Rechtbank van Koophandel - te Antwerpen, in 26 Rechtsxundig WeEkBLAD col. 1959 (1963) ; Bundesgerichtshof (Kartellsenat), June 14, 1963, ("Trockenrasierer"), in 17 NJW 152 (1964); compare Schumacher, sutpra note 99, at 364 .

For further examples, see Riesenfeld \& Buxbaum, supra note 87, at $158 \mathrm{n.22}$; compare Gotzen, Exclusivités d'approvisionnement, primes de fidelité, abus de prissance économique et concurrence deloyale, 78 Journal Des Trubunaux 705 n.6 (1963).

The apphicability of state antitrust laws to situations conceivably reachable under federal statutes in the United States offers a constructive analogy. The best recent discussion of this problem is by a German writer; see Schwartz, Das Verhältnis des einzelstaatlichen zum BundesAntitrustrecht, 124 ZeITSCHRIFT FÜR DAS GeSAMTE HANDEISRECHT UND WIRTSCTIATSRECHT 254 (1962).

106 That article 177 may be expanded to allow such "application questions" to reacli the Court of Justice in the dress of "Treaty interpretation" has no bearing on a national court's right to keep application questions from reaching the Community Court.

107 Cf. Case Nos. 28-30/62 Da Costa, Jacob Meijer N.V., Hoechst-Holland N.V. t. Ncderlandse Administratie der Belastingen, 9 Rec. Cour 63 (1963), translated in CCH Common Mre. REP. 8010 (1963); see Daig, Die Gerichtsbarkeit in der Europäischen Atomgemeinschaft, 83 ARChIV des ÖFFentLICHEN ReICHTS (N.S.) 132, 196 (1958); Catadano, La ComtinitA Econonaca Europea e' I'Euratom 36 (1957).

Something like this was done in Oberlandesgericht Frankfurt, January 19, 1962 ("Trockenrasierer"), WuW/E OLG 483, 13 WvW 331, 333 (1963) (Ger.), relying upon Regulation No. 17 as establishing clearly the correctness of the court's position that re-import restrictions in fair trade agreements affect commerce between the Member States. Ironically the decision has been reversed by the Bundsgerichtshof (Kartellsenat), June 14, 1963 ("Trockenrasiercr"), in 17 NJW 152 (1964), on the ground that under the Bosch doctrine old agreements, timely submitted, continued valid-again, without submitting this arguable version of Bosch to the Court of Justice for interpretation. The treatment of the restrictive arrangement here in issue under German law was not fully resolved by the decision. See Völp, Gefährding der Preisbindung durch Reimport, id. at 71.

108 See note 97 supra.

109 Another avoidance of the duty rests upon the suggestion that article 85 questions arising in a temporary injunction context need not be submitted via article 177. Sce, e.g., Oborlandesgericht Mumch, May 30, 1963 ("Foto-kameras"), in WuW/E OLG 556, 13 WuW 626 (1963) (Ger.); see also Buxbaum, Antitrust Regalation Wilhin The Entropean Economic Commentity, 61 Colus. L. REv. 402, 419-20 n.70 (1961). It is another thing, of course, if a temporary injunction based upon the validity of a contract in national law is granted, pending an article 177 determination of the validity of that contract under article 85 . 
Is this dour view of the utility of the present system justified? A look at what the national tribunals are doing, imstead of what the commentators suggest they should be doing, offers some interesting confirmations of this view. To state it briefly, not a single national judiciary, including administrative courts, other than the Dutch, has utilized article 177; and except for one case, the celebrated Bosch affair, ${ }^{110}$ even the Dutch cases have involved administrative, not private litigation. ${ }^{111}$ These, however, are easy procedural cases; ${ }^{112}$ it is private litigation that creates turmoil.

There have been many, certainly over a dozen, cases where an article 177 proceeding was both logical and expectable. ${ }^{113}$ Except for Bosch, in not one did the national court honor that expectation. In the near future, of course, the issue will have to be net head-on, and it will probably arise in a difficult context, presunably like that of Consten and Riviere. ${ }^{114} \mathrm{~A}$ franchise holder will sue for unfair competition, its franchise will be challenged under article 85 , and enforcenent of its rights will hang suspended,

110 See note 27 supra.

111 This includes not only antitrust cases but all substantive felds where an interpretation of the Treaty was in order. Thus, in Soc. biscotti panettoni Colussi Milano c. Ministeri coinmercio estero e finanze, Foro Italiano III col. 143 (1963), the Council of State of the Republic of Italy, by a decision of November 7, 1962, interpreted article 31 of the Treaty as directly applicable and invalidated an inconsistent local regulation. Such an issue is at least as susceptible of interpretation as that involved in vaN GEND \& Loos, 9 Rec. Cour 1 (1963). In Germany, two decisions by administrative tribunals concerning the applicability of article 95 of the Treaty to strike down certain turnover tax impositions reached contrary results without an article 177 proceeding being initiated by either. Finanzgericht Bremen, April 9, 1963, in 9 AWD 281 (1963) (Ger.) ; Finanzgericht Munich, April 23, 1963, 9 AWD 281 (1963) (Ger.).

112 They are casy in the sense that usually it is the private party protesting an adininistrative act who urges the applicability of a treaty provision, and who thus would urge the submission of the interpretation issue to the Court of Justice, especially if in the absence of such submiscion the administrative tribunal would act on the basis of the national law only.

113 Most of these are collected in Riesenfeld \& Buxbaun, supra note 87, at $158 \mathrm{n} .22$. For inore recent decisions, see note 111 supra.

In Lagattolla c. F.e.r.g.a.t., Foro ItALIANo I col. 2049 (1963), the Corte d'appello of Turin, by a decision of June 28,1963 , held that a non-competition contract "was not so important as to constitute a danger to comnerce between the Member States," and hence did not violate article S5. Again, there was no consideration of article 177, despite the debatable and often litigated nature of the problem. See Hemard, Le refus de vente en droit communautaire et en droit interne, [1963] DALLOZ JURISPRUDENCE 556.

A "breakthrough" may have arrived as far as Luxembourg courts are concerned. A problem of parliamentary imununity, under an interpretation of the Protocol on the Privileges and Immunities of the Communities, seems to have been referred by a court of the Luxembourg Arrondissement to the Court of Justice pursuant to artiele 177. Agence Internationale D'Information Pour La Presse, Daily Bull. No. 1753 [Euratom \& Colnmon Market], p.i (Jan. 27, (1964). And a similar request may be made as a result of a private action involving morals charges; see the case reported in 7 J.O.C.E. 34 (Jan. 13, 1964).

114 See notes 49 \& 53 supra. See also the Lagattolla case, supra note 113; but see Kammergericht [Berlin], May 4, 1962 ("Fensterglas III"), in WuW/E OLG 469, 12 WuW 697 (1962) (Ger.). 
and not effected, while an answer is sought to the prejudicial question. In addition there will undoubtedly soon be more Consten situations, where one party claims the entire proceeding must be suspended under article 9(3) of Regulation No. 17 because of pending Commission action.

\section{IV}

\section{PROCEDURAL ENTANGLEMENTS AT THE NATIONAI LEVEL}

As these nettles are pushed toward the already reluctant national courts, it is worth remembering that no matter what conclusions are finally accepted in compromising with the inherent contradictions of dual jurisdiction, the execution of the jurisdictional norms laid down by the Court of Justice will be in the hands of these national courts. This is itself perhaps the best reason for expecting the Court to take a cautious approach in diminishing their powers over civil litigation. When national forms, statutorily prescribed, do not fit or allow for the procedures dictated by the federal institutions, the resolution of the conflict between these forms and Community requirements will be for the national courts, assuming of course that explicit legislative norms do not moot the dispute. The Court of Justice cannot order state action. It can only decide that certain state action violates the Treaty, leaving disobedience to other, more"diplomatic"channels. ${ }^{115}$

If the German picture is any indication, it would appear that in many cases a national tribunal's attempt to "obey" in any form the jurisdictional requirements of article 177, or of article 9(3) of Regulation No. 17, would involve it in procedural entanglements without the aid of implementing municipal legislation; indeed, perhaps in conflict with existing legislation. ${ }^{116}$ More important, the differences between the systems offer ample

115 See text accompanying note 159 infra.

116 It seems, however, that the problems here discussed may not be encountered in some of the Member States. Clearest is the Italian situation. There the coinmon Protocols, including that concerning the Court of Justice (article 20 of which describes the procedures to be used before the Court in article 177 cases), were separately ratified. In the statute approving that ratification, a specific article orders the use of the article 177 procedure by the Italian courts. Law of March 13, 1958, art. 3, [1958] 1 LE LEGGr 1319-20 (Italy). That this, plus the earlier statute approving ratification of the Treaty of Rome itself, amounts to a complete transformation of these provisions into municipal law, see Miele, L'esectzione nell'ordinamento italiano degli atti internazionale institutivi della Comunita Economica Europea' e dell'Euratom, 15 Diritio Internazionate 17 (1961).

In the Netherlands, the decision of the Bosch court to seek an article 177 decision was immediately appealed to the Hoge Raad. See note 103 supra. The effect of that court's decision was to confirm for Dutch courts the legitimacy of the suspension or stay order needed in an article 177 proceeding. In any event, the Dutch statutes approving ratification of the Treaty included a special statute covering the Protocols. Law of Dec. 5, 1957, [1957] StaAtsBrad No. 495 (Neth.). For the ratification and legislative approval situation elsewhere, see Riesenfeld \& Buxbaum, supra note 87, at 156-57 n.15. 
opportunities to hostile courts to thwart the application of Communitydictated procedures. The suspension of proceedings affords a good example. In primciple this is not foreign to German civil procedure. There, as elsewhere in Continental systems, the suspension of proceedings is a common device used in a uniform fashion in all types of litigation. ${ }^{117}$ The partial American analogue, primary jurisdiction, has developed only sporadically out of niterpretations of particular statutes which estabhsh regulatory agency schemes over the subject matter of the civil litigation. While there is also general learning on yielding jurisdiction to courts in other situations, this has little bearing on the problenı of fitting administrative regulation into the judicial system. Once an American court is faced with a situation lying beyond these means of solving problems of conflicting decisions, it solves them retrospectively by applying doctrines of res judicata, nicluding collateral estoppel. ${ }^{118}$ In Germany, on the other hand, where a relation between the parties as well as an identity of issues is needed to apply the doctrime of res judicata, ${ }^{119}$ the concept underlying the doctrine can also be used prospectively to determine the feasibility and usefulness of the suspension procedure in any given case. Where the agency decision, if already made, would be res judicata in the present litigation, the court can forestall the need to use the doctrine retrospectively by suspending proceedings in favor of an immediate agency ruling.

Nevertheless, there exists no specific, easily usable warrant in the German Code of Civil Procedure for staying an article 177 case while requesting a prejudicial decision, and certainly none for suspending litigation in midstream because of the initiation of Commission proceedings under article 9(3). It has been suggested, perhaps a bit casually, that section 148 of the ZPO (Code of Civil Procedure) will suffice for these purposes, ${ }^{120}$ but a brief review of that provision raises doubts concerning its use. First, it cannot be easily adapted to article 177 proceedings because it requires

117 See generally Millar, The Premises of the Judgment as Res Judicata in Continental and Anglo-Anterican Law, 39 Mrce. L. Rev. 1, 238 (1940); Schwarzenberger, Federalism and Supranationalism in the European Communities, 16 Current Legar Probdemss 17, 23-24 (1963).

118 See Comment, 51 CaLIF. L. Rev. 955 (1963).

119 See EHRENZWEIG, Confutct of LAws 227 (1962); Millar, supra note 117.

120 Schlieder, Comment, 9 AWD 84, 86-87 (1963). In the Trockenrasierer case, in 17 NJW 152 (1963), the Bundesgerichtshof, the highest German civil court, rejected a suggestion of the Federal Cartel Office that the proceedings be suspended under section 148 ZPO, not because of the inherent unsuitability of the provision for this purpose, but because of the detrimental result to the plaintiff of such non-enforcement of its rights. Such a disposition of the suggestion is inconclusive on the problem here discussed, but indicates how casily reluctance to accept certain substantive results can lead a court to deny the suitability of procedures assertedly available to it. See also WoHLFARTH, EverLIng, GLAESNER \& SPRUNG, DIE EUROPärsche WIRTSCHAFTSGEMEINSCHAFT, KOMIMENTAR ZuM VERTRAg 499-500 (1960). 
that the question for which a stay is sought be involved in pending hitigation elsewhere. ${ }^{121}$ The Court of Justice proceeding, of course, is not pending until a certification occurs. Section 148 is, perhaps, more suited to an article 9 (3) suspension, since it permits a stay while an answer is sought from an administrative agency, as distinguished from a court, without the need for an already pending proceeding. It is used when the agency is competent to determine the existence or non-existence of a jural relation, usually between the parties, ${ }^{122}$ which goes to constitute at least in part the source of the plaintiff's claimed rights. ${ }^{123}$ It is possible, though doubtful, that the Commission's proceeding qualifies as one determining such a jural relation. ${ }^{124}$ Further, the provision has been used to order stays in favor of agencies existing outside the sovereign structure in which the legislation was enacted, ${ }^{125}$ but so far only when the treaty provision providing therefor

121 The complete article reads: "When the decision in the hitigation is completely or in part dependent upon the existence or non-existence of a jural relation which is the subject of a pending hitigation elsewhere, or which is to be determined by an administrative authority, the court may order the suspension of proceedings until completion of the other hitigation or until the decision of the adininistrative authority." $\$ 148$ ZPO. (Author's translation.)

"Administrative authority" is a broad term of art, and includes administrative tribunals as well as courts exercising "non-contentious jurisdiction" ("freiwillige Gerichtsbarkeit"). This involves proceedings for constitutive declarations of legal relationships by administrative tribunals, before which private parties are participants rather than litigants. Sec Gesetz über die Angelegenheiten der freiwilligen Gerichtsbarkeit, May 17, 1898, [1898] Reichsgesetzblatt pts. 2-5 at 771 (Ger.). From a review of the types of subject matter (probate, commercial register, marriage, family and legitimacy declarations, etc.) it seems doubtful that the concept can readily be read to include the Court of Justice article 177 proceedings. Sec Keidet, Freiwilitee Gerichtsbarkeit (8th ed. 1963); see also Rosenberg, Lempiuci Des DEUTSCHEN ZTVILPROZESSRECETS 52-57 (9th ed. 1961).

122 Identity of parties in the two proceedings is customary, but not required, at least where both are simultaneously pending judicial proceedings. Reichsgericht, March 12, 1896 (VI Senat), in 25 JURISTISCHE WOCHEASCARIFT 203 (1896). Section 148 has been used where the issue in the administrative proceeding was the effect of a public law provision on the cause of action of the complainant in the first case, but both proceedings involved the same two parties. E.g., Reichsgericht, November 21, 1911 (VI Senat), 77 Entscheidungen des Reichgerichts in Zivilsachen 411 (Ger.); see 1 Sydow, Busch \& KrantZ, ZrviLProzessordnunc 221 (20th ed. 1930).

123 Where the same parties are not involved, the binding effect of the second decision is doubtful. See Tiffert, Bürgerliche Rechtsstreitigkeiten, in MüLter-Henneberc \& Schwartz, Gesetz Gegen WettbewerbsbeschänRungen, Komanentar 839, 880 (1958) (1963 ed. not available at time of writing). As this indicates, the principal reason for using such a provision is to regulate what in our federal system become problems of res judicata and collateral estoppel. See text accompanying notes 117-19 supra.

124 See Rosenberg, op. cit. supra note 121 , at 414-15.

125 The principal example appears to he article 16 of the Convention on the Rights and Obligations of Foreign Forces and their Members in the Federal Republic of Germany, [1955] 2 Bundesgesetzblatt [hereinafter cited as BGB1] 301, 321, which requires a temporary and limited stay of proceedings in order to obtain a factual "line of duty" determination, if that is relevant to the hitigation before the court. 
contained detailed prescriptions for the manner of proceeding and the use to be made of the foreign determination. ${ }^{126}$

In any event, other more serious considerations militate against the use of the provision. The stay is in the staying court's discretion, contrary to the entire aim of article $9(3) .{ }^{127}$ Only in a few cases specified in other statutes is the granting of a stay made mandatory. ${ }^{128}$ Even in these latter cases the courts have refused to order stays on grounds available to them in the Community context. ${ }^{129}$ Indeed, the court's use of the prejudicial decision is a matter for its discretion, ${ }^{130}$ and this has been claimed as a reason for not ordering even a purportedly mandatory stay.

The grounds for normal suspension of proceedings ("Aussetzung") "by operation of law" rather than by court discretion are listed in section 246

120 The determination is not conclusive upon the first court. Convention, art. 16(3). This situation is sui generis and not of precedential value for our discussion. The Convention was approved for ratification and indirectly transformed into local law. See Law of March 24, 1955, [1955] 2 BGBI 213 (Ger.); compare the Treaty of Rome ratification, note 140 infra. Further, this provision includes extremely detailed instructions for the German courts. Finally and most important, acceptance of all commitments of this Convention was, inter alia, the means by which the Federal Repubic assumed sovereign status after the Occupation period. Other parallel conventions of that date contam similar but less relevant provisions. See STEIN \& JoNas, KOMMAENTAR ZUR ZIVILPROzESSORDNUNG, § 148, at 2 (1953, Supp. 1960).

127 This, however, may be limited if the stay was not a matter of discretion. See BAUMBACE-LAUTERBACH, ZivILPROZESSORDNUNG 301 (27th ed. 1963).

128 The best example being that created by article 96(2) of the German Cartel Law: "If the decision in a case depends entirely or in part upon a decision that is to be taken pursuant to this statute, the court shall suspend the proceedings until the decision of the authorities and courts [exclusively] competent under this statute ... ." Law of July 27, 1957, [1957] 1 BGBI 1081 (Ger.). This provision, necessary to safeguard the exclusive jurisdiction of the Federal Cartel Office and appellate courts to apply the Cartel Law, is called a deviation from $\S 148$ ZPO by one authority. BAUMBACH-HEFERMEEI, WeTtBewerbS-UND WARENZEICHENRECHT 1477 (8th ed. 1960). For a discussion fitting it a bit less reluctantly imto $\$ 148$ procedures, though indicating the many deviations, see Tiffert, supra note 123, at 878-82.

For more examples of such receiving statutes specifically requiring deviations from $\$ 148$, see 1 SteIn \& Jonas, op. cit. supra note 126 , $\$ 148$, at $7-12$.

129 Thus, in its judgment of July 10, 1959 ("Nescafé"), in WvW/E BGH 383, $10 \mathrm{WvW}$ 361 (1960), the Bundesgerichtshof refused to require a stay under $\S 148$ ZPO for a prehiminary decision of the Federal Cartel Office pursuant to $\S 96$ of the Cartel Law where the civil hitigation could be decided on undisputed facts. This avoidance of the mandatory stay is related to the general proposition that the second court's decision must be res judicata for the first proceeding before the staying court is required to abide by it. $C f$. Bundesgerichtshof, June 15, 1959, 30 Entscheidungen des Bundesgerichtshofes in Zivilsachen [hereinafter cited as B.G.H.Z.] 186 (Kartellsenat 1959); see Baunrach-LAUTERBACH, ZIVILPRozEssoronung 298 (27th ed. 1963). Thus, German law could not easily give mandatory effect to a prejudicial decision, which is based upon a relatively abstract presentation to the Court of Justice. As for article $9(3)$ suspensions, the subsequent Commission action might not achieve this res judicata status depending inter alia upon the problem of identity of parties. See note 123 supra.

130 This, again, may not be discretionary depending upon the reason why the stay and certification was ordered. See 1 Syoow, Busch \& KrANTz, op. cit. supra note 122, at 219. Compare, however, the situation discussed in note 124 supra. 
ZPO; they do not include suspension to permit referral of questions to the Court of Justice or Commission. ${ }^{131}$ Another ZPO provision prevents a second court from taking jurisdiction over a second case raising these issues between the same parties. ${ }^{132}$ This provision could be read to prohibit one of the parties from making such a request, though admittedly the bar is addressed to courts subject to the ZPO ${ }^{133}$ Here, also, there exist further analogous procedures under German law concerning the suspension of proceedings while questions are certified to special courts-in particular, issues of constitutionality sent to the Federal Constitutional Court. ${ }^{104}$ These, however, also exist only by virtue of statutes creating special "receiving" courts, just as is the case with the few "receiving statutes" requiring a stay under section 148 ZPO. ${ }^{135}$

In this situation, the only method of directly applying article 177 and Regulation No. 17 is to consider them as "receiving statutes" by analogy to these local legislative intrusions upon the normal civil procedural rules. ${ }^{100}$ From the viewpoint of the Court of Justice, interpreting the intention of the Treaty as a matter of Community law, this intention to achieve direct apphicability would undoubtedly be affirmed. The ability of the German courts to honor this intention, however, is not so clear. First, there is a special

131 This is self-evident since the provision has not been amended since before the ratification and effective date of the Treaty of Rome.

$132 \S 263$ (2) ZPO.

133 Ibid.

134 In the case mentioned in the text, see article 100 of the Basic Law (Grundgesetz fur dic Bundesrepublik Deutschland, May 23, 1949, [1949] 1 BGBI (Ger.) [hereinafter cited as Basic Law] 1), and $\$ 13(11)$ of the Law concerning the Federal Constitutional Court (Gesetz über das Bundesverfassungsgerich) March 12, 1951, [1951] 1 BGBI 243 (Ger.). From this analogy, one writer has drawn the conclusion that in Germany no appeal can be taken from a lower court decision to use article 177. Ehle, supra note 103. He does not, however, question the present power of the courts to use article 177 , which indeed seems generally assumed.

135 Note 128 supra.

136 Given the form of the German ratification of the Treaty of Rome, it seems that at least a ministerial regulation, if not a separate amendment of the ZPO, may be needed to open the way for the use of article 177 by German courts. It has been suggested that the national Ministries of Justice are competent to regulate the use of article 177 within national procedural structures. Wohlfarth, Everling, Ginesner \& Sprung, Die Europötsche WirtSCHAFTSGEMEINSCHAFT, KOMMNENTAR ZUM Vertrag 500 (1960). Compare, however, the more careful treatment of this matter in the Italian legislation, note 116 supra. Admittedly, none of this has been suggested by those decisions mentioned in the text accompanying notes 110-13 supra; they have always found substantive reasons of more or less plausibility for not utilizing article 177.

Many of the problems here discussed could be resolved through a determined effort at larmonization of national procedures under the aegis of articles 100 and 220 of the Treaty. The excellent study on this subject by Nager, AuF deM Wege ZU edneM europärschen ProzessRECHT (1963), became available to me only after this article was written; it should be consulted in any discussion of this sort although it is primarily a comparison of French and German civil procedure. Concerning the effect of otherwise pending proceedings upon a national court's jurisdiction, see id. at 94-98. 
problem. German law follows the doctrine of transformation of certain types of international treaties (those involving matters for which the federal legislature would normally be competent) into municipal law through the procedure of legislative ratification under article 59(2) of the Basic Law. ${ }^{137}$ According to the Federal Constitutional Court, this transformation is normally effected by a ratification statute that adopts-actually, publishes in the official gazette- the treaty "with the force of law" ("mit Gesetzeskraft"). ${ }^{138}$ This was the form in which the treaty establishing the European Coal and Steel Community was ratified by the German Bundestag. ${ }^{139}$ It was not the forn in which the Treaty of Rome was ratified, ${ }^{140}$ and the difference may be a significant deterrent to an easy ruling of direct applicability through transformation. ${ }^{141}$

More generally, but with respect to Regulation No. 17 only, the ratification statute contains no express acceptance of subsequent Council regulations, enacted through the delegation of powers to the Council of Ministers contained in the Treaty. Indeed, the statute specifies that certain Treaty obligations in the specific field of tariff reductions, which require detailed formulation by Council regulation, can be enacted as internal law by governmental edict with only limited veto powers in the legislature. ${ }^{142}$

137 "Treaties which regulate the political relations of the Federal Republic or which concern subjects of federal legislation require the approval or collaboration of those bodies responsible for such federal legislation, in the form of a federal statute ... ." Basic Law, art. 59(2). (Author's translation.) See generally Maunz \& Dürrg, GrondGesetz Komarentar, art. 59, 8-11 (2d ed. 1963); Seidl-Hohenveldern, Transformation or Adoption of International Law into Mamicipal Law, 12 INT's \& CoMrp. L.Q. 88 (1963).

138 Judgment of July 30,1952 , Bundesverfassungsgericht, 1 Entscheidungen des Bundesverfassungsgerichts 396,411 (1952) (Ger.). "The statute of ratification also operates to" lend to the treaty its validity as internal German law (Transformation). This is evidenced with particular clarity in the prescription, now generally used in these statutes, whereby the treaty shall be published 'with force of law.'" (Author's translation.) See MAUnz \& DürIG, op. cit. supra note 137 , art. 59, 13-16.

139 Law of April 29, 1952, [1952] 2 BGBI 445 (Ger.). See Balladore Pallieri, Les pouvoirs des organisations économiques européennes à l'intérieur des Etats membres, 23 ZEITSCHRIFT Für AUSLÄNDISCHES ÖFFENTLICHES RECHT UND VöLKERRECHT 473, 479-80 (1963).

140 Law of July 27,1957 , art. 1, [1957] 2 BGBl 753 (Ger.), which prescribes the publication of the Rome Treaty, but witllout the magic phrase.

141 See note 135 supra.

A procedure similar to article 177 is contained in article 41 of the ECSC Treaty; see Jerusalear, Das Recit der Montanunion 60-61 (1954). The duty of German courts to obey this "preliminary question" requirement was suggested in vague dictum by the Bundesgerichtshof, April 14, 1959 (VIII Senat), 30 B.G.H.Z. 74, 77-78 (1959). But the difference in ratification alone inakes the precedential value of this comment somewhat doubtful. See

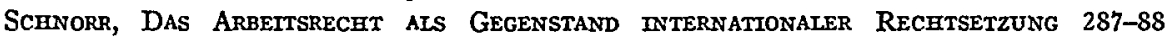
(1960); compare Knopp, Uber die Pficht deutscher Gerichte zur Vorlage von Auslegungsfragen an den Gerichtshof der Europäischen Gemeinschaften nach Art. 177 des EWG-Vertrages, 16 JURISTENZEITUNG 305, 309 (1961).

142 Law of July 25, 1957, art. 3, [1957] 2 BGBI 753 (Ger.). 
In all other cases in which Council "decisions" ${ }^{143}$ generate directly applicable internal law or require the enactment of implementing statutes, the government must advise the legislature before the "decisions" are even taken by the Council of Ministers. ${ }^{144}$ This cautionary approach indicates that the direct applicability of a provision like article $9(3)$ is hardly selfevident. The whole issue of the superiority of regulations enacted by this international organization over national law is also not yet resolved; ${ }^{145}$ this too will affect the ability of national courts to accept the denial of competence required by article $9(3)$.

Assuming that the unusual wording of the German ratification statute is unimportant and assuming that the required transformation occurred, the direct applicability of any particular Treaty or regulation provision must still be settled under general principles of German law. ${ }^{146}$ Transformation apart, the possibility of delegating legislative functions to international organizations seems to be foreseen in the Basic Law. ${ }^{147}$ Moreover, the direct applicability of generally accepted rules of international law (including, when appropriate, rules contained in conventions) ${ }^{148}$ is also specified. ${ }^{149}$ Neither provision, of course, determines the direct applicability of any particular treaty provision, let alone the applicability of a particular regulation enacted under delegation of authority contained in such a treaty. ${ }^{150}$ This is achieved by an old formula of constitutional law whereby

143 This is not intended as a term of art, but probably includes Couneil regulations. Sec also Bebr, The Relation Of The European Coal And Steel Community Law To The Law Of The Member States: A Peculiar Legal Symbiosis, 58 Corum. L. Rev. 767, 769 n.13 (1958).

144 Law of July 27, 1957, art. 2, [1957] 2 BGBl 753 (Ger.). See Stein, The New Iustitutions, in 1 Sten \& Nicholson, American Enterprise IN The European Common Market: A Legar Profine 33, 95 (1960).

145 Compare Bebr, supra note 143, at 771-74, 788-92. The question is not only that of the rank of such regulations in the internal legal hierarchy, id. at 782-83, but of the effect of these priority and conflict problems on this very delicate and specific Community regulationnational civil procedure conflict. See Bebr, Judicral Control of tHE EURopean ComMUNITIES 216-26 (1962).

146 Bundesgerichtshof, May 24, 1955 (I Senat) 17 B.G.H.Z. 309, 313 (1955). Without an internal transformation by statute, no direct private effects can follow. Ibid.

147 "The Federation may by statute transfer sovereign rights to international institutions." Basic Law, art. 24(1).

148 See Münch, Délimitation du domaine du droit des Communautés supranationales par rapport au droit étatique interne, in Centro Italiano Di Studi Giurudici, 2 Actes Ofriciets Du Congres International D’Etudes Sur La Communauté Européenne Du Charbon ET DE L'ACIER 271 (1957), especialiy id. at 285-292.

149 Basic Law, art. 25.

150 Even in a country like the Netherlands, where the direct and superior applicability of international law, including Council regulations, in national courts seems assured (sec Erades \& Gould, The Reiation Between International Laiv and Municipal Law in tiwe Netherdands aNd IN tHe United States 198, 307 (1961); Bebr, stepra note 143, at 776-77), there is a lively controversy concerning the proper interpretation of that formula in any given case. See, e.g., Erades, Poging tot ontwarring van de "self-executing" knoop, 1963 NederLands 
the content, purpose, and form of the treaty provision must clearly evidence this applicability, ${ }^{151}$ a formula similar to that used by the Court of Justice in van Gend $\mathcal{E}$ Loos. $^{152} \mathrm{It}$ is possible that the tests are not identical. The central problem from the national point of view is whether the treaty provision is self-executing. Depending upon the subject matter and the national legislative ground upon which it is to operate, what is intended to be a directly internally applicable enactment is not necessarily self-executing. ${ }^{153}$ The best examples of this disparity lie in the field of civil procedure itself. It is one thing to say that rules concerning stays and suspensions are intended to be at once directly applicable within each Member State. It is quite another to assume that they are "self-executing" within a procedural framework that is not reworked to accommodate them. In contrast, rules of substantive law can more easily be treated alike under both tests. ${ }^{154}$ If this distinction is valid, the direct use of article 9(3) and perhaps of article 177 may depend upon a test that is more stringent than the normal formula by which the competent national judge decides the direct apphicability of a treaty provision. ${ }^{155}$

In any case, assuming the direct applicability of these enactments, German courts would still be able to deny effect to the rulings of the Court of Justice on grounds already cited: The absence of a factual context in the article 177 interpretation prevents the application of res judicata principles to the prejudicial decision, and therefore permits the German receiving

JURISTENBLAD 845, 850-51 (difference between Community law applied as municipal law, and having a direct effect in internal law).

161 Bundesgerichtslof, May 24, 1955 (I Senat) 17 B.G.H.Z. 309, 313 (1955). See Knopp, supra note 141 , at 308 .

15: 9 Rec. Cour 1 (1963).

153 At least one writer has made an excellent study of the general views on the superiority of Community law in the light of the "self-executing" problem, without, however, drawing these conclusions or distinctions. Hayoit De Termicourt, Le conflict "Traite-Loi interne," 78 Journal Des Trubunaux 481 (1963); see also Van Hecke \& Suetens, Le premier règlement europén sur les cartels et les monopoles, 77 id. at 362 (1962). For a broad survey of Rome Treaty provisions reviewing the internal effect of each, see Report of Working Group, Nederlandse Vereniging voor Europees Recht, Welke Artikelen Van Het Verdrag Tot Oprichting Van de Europese Economische Gemeenschop Moeten Als Een Ieder Verbindende Bepalingen Worden Beschouwd?, 11 Soc. Ec. WET. 545 (1963), especially at 555-56, 575-80.

154 See note 164 infra.

156 This subject has been exhaustively discussed. See especially Catalano, Manued DE Droit Des Concarunautés Européennes 115-26 (1962); Bebr, The Relationship Between Community Law And The Law of The Member States, InT'x \& Comp. L.Q. (Supp. No. 4) 1 (1962); Gaudet, Incidences des Communautés Européennes sur le Droit interne des Etats nembres, 1963 ANnales DE LA Faculté dE DRoTt de LTEge 5; Schlochauer, Das Verhältnis des Rechts der Europäischen Wirtschaftsgemeinschaft zu den nationalen Rechtsordnungen der Mitgliedstaaten, 11 ARCHIV DES VöLKERRECHTS 1 (1963); Wohlfarth, Europäisches Recht. Von der Befugnis der Organe der Europäischen Wirtschaftsgemeinschaft zur Rechtsetzung, 9 JAFRBUCH FÜr. INTERNATIONALES RECHT 12, 30-32 (1962). 
court to ignore it. This situation, which is a challenge to the forced use of section $148 \mathrm{ZPO}$, is equally a challenge to the uniform and respectful application of article 177 .

In either event, of course, the national court, in reaching this determination, may wish to inquire of the Court of Justice, via article 177, as to its understood obligations as a matter of Community law. That is what the Dutch Tariff Commission achieved in van Gend $\mathcal{E}$ Loos, $^{160}$ and the Court of Justice there was careful to limit its answer so as not to impinge upon the Dutch tribunal's constitutional functions. ${ }^{167}$ In essence this is an advisory opinion. ${ }^{158}$ It warns the national court that any contrary substantive decision will lay open that Member State to a charge of violating the Treaty or of failing to carry out its obligations thereunder. Of course the commitments laid upon its signatories by the Rome Treaty contemplate that certain of its provisions be given internal effect, ${ }^{150}$ but that, without more, is not a reason for an overly broad interpretation of either of the articles here under discussion, and especially of article 9(3) of Regulation No. 17.

Perhaps all this has only been a less elegant way of stating Stein and Hay's comment that the Court of Justice lacks certiorari powers. ${ }^{160} \mathrm{My}$ purpose, however, is to lend color to the suggestion that the Court of Justice will not interpret unclear Treaty or regulation norms so as to encourage hostility from the national courts. Constrained in any event to follow the

1569 Rec. Cour 1 (1963).

167 See Riesenfeld \& Buxbaum, supra note 87, at 156. Concerning the limited right of the Dutch courts to exercise any such functions, see van Panhuys, The Netherlands Constitntion And International Law, 58 Ax. J. INT'L L. 88 (1964); authorities cited note 150 supra.

168 In other words, failure to honor Treaty ohligations because of municipal law barriers is not made more reprehensible by a supplemental refusal, for the same reasons, to apply article 177. This has heen clearly recognized in other situations under article 192 of the Treaty, as for example the dispute concerning local execution of Conmunity decisions and judgments. Cf. Schïtze, Die Nachpriifung von Entscheidungen des Rates, der Kommission tutd des Gerichthofes nach Art. 187, 192 EWG-Vertrag, 16 NJW 2204 (1963); see Ropers, Le Marchè commun et les effets internationaux des judgments répressifs, [1963] SEMaINE JURIDIQUE 1797 ; Runge, Die Zwangsvollstreckung aus Entschéidungen der eıtropäischen Gemeinschaflen, 8 AWD 337 (1962).

In this sense, article 177 permits the Court of Justice to give advisory opinions to the national courts as to the meaning of the Treaty. In my opinion, this is what the Court of Justice said in van Gend \& Loos, 9 Rec. Cour 7 (1963). Cf. Donner, National Law and the Case Law of the Court of Justice of The European Communities, Coman Míx. L. REv. 8 (1963). But see Hay, Federal Jurisdiction of the Common Market Court, 12 Ax. J. CoMr. L. 21, 37 (1963).

159 The judiciary's actions are, of course, state actions. Articles 169 and 170 allow the Commission or a Member State, respectively, to conplam to the Court of Justice of such a violation; article 171 provides that upon a finding thereof, the Member State "shall take the measures required to implement the judgment." Treaty, art. 171. Indirectly, then, through articles 169-71, a national refusal or mability to apply article 177 or article 9(3) of Regulation No. 17 will be reviewable. See generally BEBR, op. cit. supra note 145, at 158-59.

160 Stein \& Hay, New Legal Remedies of Enterprises: A Survey, in 1 STEnN \& Nicnolson, op. cit. supra note 144 , at 480 . 
basic law common to the legal systems of the Member States, ${ }^{161}$ the Court of Justice will probably interpret article 9(3) as narrowly as possible to avoid conflicts with relevant state procedures in this area. For example, when the question arises whether national courts are authorities, or whether the national authorities may hear charges of an article 85(1) violation following a submitted but not yet processed notification, the present procedural posture of at least the German courts should operate as a restraint against overly expansive interpretations.

This is not to suggest that national tribunals are likely to hunt out such or other hindrances to the use of the article 177 procedure. ${ }^{162}$ It is to emphasize that internal difficulties in harmonizing this procedure with national civil procedures will and should lead to caution in expanding the role of article 177 , and a fortiori to great caution in expanding the role of a procedure devised not by the Treaty but by Council regulation. Of course this is a general problem. The "federal" structure created by the Treaty does not pretend to be complete, and rests for its extension upon the sovereign states that created it, not upon itself. ${ }^{163}$ In this area, however, the most sensitive and deeply ingramed of the non-political national interests are touched-those inherent in the civil procedural rules of each nation. ${ }^{164}$ At this stage in the Community's federal development it would undoubtedly be risky to adopt doctrine that added to rather than minimized the need to jettison established state rules. There will be enough conflicts of substantive law to harass the national authorities, including the legislatures, as the Community's functions expand. ${ }^{165}$ Federal developments that bring procedural rules into the battle, and so heighten the danger of revolt within, ${ }^{166}$ will probably be avoided by the Court of Justice for the time being. ${ }^{167}$

181 See Treaty, art. 164. See generally Friauf, Die Notwendigkeit einer verfassungskonformen Ausleging in Recht der west europäischen Gemeinschaften, 85 ARCHIV DES ÖFFENTITCHEN RECHTS 224 (1960), especially at 228, where he distinguishes between the overall primacy of the Treaty of Rome and the constraints therein imposed along the lines here suggested. See also, though in a different context, Ehle, Wirtschaftslenkung und Verfassungsrechtsschutz im Genreinsamen Markt, 9 AWD 157 (1963).

162 But see the record to date as displayed in text accompanying notes 111-13 supra.

163 See Riesenfeld \& Buxbaum, supra note 87, at 157 .

104 See the related comment in ROSENBERG, op. cit. supra note 121, at 18, that uniformity in the field of civil procedure is far more important than in substantive private law fields.

${ }^{105}$ See Commission of the European Economic Comparuntax, Meamorandum ConCernang the Action Prograsone passim (1962); Ipsen \& Nicolaysen, Das Aktionsprogramm für die zweite Stufe und Bericht über die aktuelle Entrericklung des Gemeinschaftserechts, 16 NJW 1713 (1963).

${ }^{168}$ For a succinct description of the turmoil occasioned by the French decisions discussed in text accompanying notes 49-53 supra, see Goldstein, Administrative Shaping of French Refusal to Deal Legislation, 11 Axr. J. Costr. X. 515, 536-37 nn.53 \& 54 (1962).

107 For a criticism of the Court of Justice's conservatism in expanding Community powers generally, a trait more suitable in the field under discussion in this article, see Lecourt \& Chevallier, Chances et malchances de l'harmonisation des legishations européennes, [1963] DaLIOZ JURISPRUDENCE 273, 279. See also Schwarzenberger, supra note 117, at 29. 
From relatively abstract but important considerations the existence of an overly centralized enforcement structure in the Community has been shown to be both questionable and for the near term unlikely. Is it now possible, if not to predict the exact course of developments, at least to chart a feasible range thereof? This question requires a closer scrutiny of the possible inconsistent results arising from the freedom of national courts to proceed with pending litigation within the limits previously suggested. These possibilities of conflict can best be illustrated by hypothetical situations, from which can be gauged the intensity of the conflict and the degree of detrimental reliance that national decisions may engender. From these examples it should be evident that the apparent problems of stability and reliance are not overly important barriers to national action, ${ }^{188}$ even if they

${ }^{168}$ Another possibility is to compare the experience of other federal systems in harmonizing concurrent jurisdictional powers. Since in the Member States the accommodation of coexisting sovereign structures has not recently been of major concern, the most likely source of perspectives is the experience in the United States. Nevertheless, while many instructive analogies exist, most of them are only superficially relevant. This is primarily because our federal-state conflicts are truly and forcibly resolvable through a federal judiciary and executive operating under a complete federal constitutional structure.

For example, the consideration of factual issues involving federal antitrust questions by state courts may result in findings binding upon federal courts in later actions, whether on a res judicata or collateral estoppel theory (depending upon the parties and the issues). See Comment, 51 CaLIF. L. Rev. 955 (1963). The use of prior decisions is less of an issuc in civilian structures, however, because of the different approach to these "res judicata" concepts. See note 122 sicpra. Further, the nature of the Conimission's functions, especially the exemption functions, makes it less desirable in any event to hold to doctrines of preclusion. While somewhat the same might be said of the Federal Trade Commission, this body does not exercise anywhere near the degree of administrative discretion delegated to the Commission. In addition, prior state decisions, since they arise only as matters of defense in contract actions and the like, are too rare to have been a factor in the FTC's later conduct towards identical problems. In the reverse situations, state courts arc free to apply state antitrust laws despite the pendency of previous existence of FTC proceedings under federal law against the same situation. Wisconsin v. Allied Chem. Dye Corp., 9 Wisc. 2d 290, 101 N.W.2d 133 (1960). That this comports with the continuing jurisdiction of Member State courts wherc national law covers the same factual situation as Community law, see note 105 sttpra.

A closer analogy may be the labor law field, in which the nature of the problems makes the theoretically exclusively federal jurisdiction much harder to obtain, and in which the competent agency does have wide discretionary powers that even include exemption of violators from sanctions, if needed to achieve the public aims of the National Labor Relations Act. See NLRB v. Thayer Co., 213 F.2d 748 (1st Cir. 1954). Even in these cases, of course, the state courts are applying state law, not federal law; for example, they decide that a strike was a breach of the peace as a matter of state law. Sec Johnston v. Colonial Prov. Co., 128 F. Supp. 954 (D. Mass. 1954). That this means the activity was not "peaccful" in order to be protected concerted activity under section 7 of the act should hardly bind the federal agency, at least if the agency could not influence the state court finding (and it should not, 
are formal barriers to the use of article 177 as a conflict-resolving device. These examples are offered not as final answers, but as leads to a method of analysis, for it appears that only through analyses of this sort can arguments on either side of the centralization issue be judged.

(1) An exclusive distributor charges a competing outsider with unfair competition under national law, and is met by a defense that its exclusive franchise violated article 85(1). The court rejects the defense, holding that article 85(1) is not violated, and no certification to the Court of Justice is made. The Commission rules otherwise in a later situation involving another manufacturer's similar agreements. The following considerations would be relevant to the question of detrimental reliance:

(a) If the agreement upheld was non-notifiable (the most likely situation) the issue of reliance is not reasonably involved. Enterprises have participated in such agreements as if they were legal all along, under the non-notification umbrella. ${ }^{169}$ Later Commission action against thein will be no more upsetting to busmess expectations because of the prior decision than without it.

(b) If the agreement upheld was notifiable, and the Commission has been notified of all or most of such agreements, all parties in that posture realize that they have already submitted the issue involved in the national litigation to Commission jurisdiction and disposition. The prior decision has not led them into making different arrangements; at worst, it "deceives" them into continuing present ones that reflection might have led them to abandon.

(c) Since the difference between notifiable and non-notifiable agreements is on the whole clear, the only further factor to be considered in the case of new agreements is whether parties, who would normally immediately notify the Commission upon execution thereof, may decide not to do so because of reliance upon the national court's decision that these are not even within article 85(1). This is not a common situation since, generally speaking, agreements upheld in national courts will likely be non-notifiable. As to them, parties would be equally willing to participate if there had never been such a national decision, again relying upon the non-notification umbrella. There could, however, be agreements definitely notifiable and yet in a given instance upheld by a national court. Even then there is no real problem of involuntary rehance: Parties interested in entering similar

for obvious reasons). The Thayer court's suggestion that the possibility of United States Supreme Court review by means of certiorari request might suffice to "hold" the agency to the state court proceedings seems unrealistic in light of Fay v. Noia, 372 U.S. 391 (1963). See also Braverman \& Gerson, The Conclusiveness of State Court Decrees in Federal Tax Litigation, 17 TAX L. REv. 545, 546 (1962).

169 See Regulation No. 17, art. 4(2); note 58 supra. 
agreements may utilize the negative attestation procedure, ${ }^{170}$ by which the Commission may be asked as a precaution whether it finds the agreement within article 85(1). Indeed, they can hardly claim detrimental reliance in good faith; an agreement otherwise notifiable when entered into should at the least be submitted to the Commission when a national court interposes to call it legal. In addition, even if non-notifiable, such an agreement can again be voluntarily submitted upon an application for either a negative application or exemption. One of these two routes should be traveled by any enterprise interested in using a national holding of validity of an otherwise doubtful practice as its warrant for engaging in such a practice. Failure to do so should obviate any question of detrimental reliance.

(2) An exclusive distributor charges a competing outsider with unfair competition in a national court and is met by a defense that its exclusive franchise violates article 85(1). The court agrees and finds an article 85(1) violation. The Commission later finds otherwise as to similar agreements or at least exempts this or another such franchise under article $85(3)$. The following considerations would be relevant to the question of detrimental reliance: $:^{\mathbf{1 7 1}}$

(a) Since a state court caunot grant an article 85(3) exemption, there can be no reliance upon any finding of a violation. The business community is charged with knowing that the Commission can exempt this very agreement, not to mention others. Thus, it can hardly base a change of conduct upon this result, at least as concerns the continued use of already existing and submitted agreements of this type.

170 See note 38 supra.

171 Another approach to this problem is to weigh the values of reliance and stability against the value of effectuating public policy and awarding relief to litigants. Consider, for example, the decision discussed in note 56 supra. The result of the unnecessary abstinence is to thwart the application of Community and of national antitrust principles. A rebate cartel whose mode of operations arguably violates both laws is allowed to operate in default of legal control, because of a dogmatic fear of entirely hypothetical consequences, and despite the clear grant of authority, in artiele 9(3) of Regulation 17, to national agencies. In each such cases, it might well be asked what the deleterious effects of exercising jurisdiction migbt be. Here, at the worst, the Commission at some indefinite later date might decide that a rebate cartel need not grant volume discounts for purchases from non-meunbers in other EEC countries. In that case the cartel could again draw its procedures more tightly against non-member producers, motivating customers to shift orders away from such competitors and back to its members. What values of reliance and stability are violated? How important is it that other rebate cartels opened their doors for outsiders as a result of the earlier decisions?

As for the retroactivity speculation, see text accompanying notes 178-80 infra. It could, in addition, be argued that the express grant of competence in article $9(3)$ to national authorities to proceed despite the possibility of a notification for exemption purposes is intended as a limit on the Commission's power to extend the exemption retroactively, though not, of course, against its power to grant the exemption. 
(b) As to the inhibition on the use of future arrangements of the type held illegal, any problem of reliance can be minimized by the application of the parties for a negative attestation or an exemption. ${ }^{172}$ An affirmative Commission decision as to either matter recreates the warrant to use this type, prevents a national decision against the particular agreement, and in addition lessens the possibility of another national court ruling against such agreements.

(c) That leaves old agreements of which the Conmission was not notified. If they are non-notifiable agreements, the conclusions in (a) apply. If they are for some formal reason not of this type, ${ }^{173}$ they can no longer be exempted by the Commission, which thus inust decide whether to hold them not violative of article $85(1)$, in contradiction to the prior local ruling. Here, and apparently only here, the situation is somewhat troublesoine. A contrary decision means, $m$ effect, that the abstinence by firms from this kind of arrangement proved to be unnecessary, and that victory for outsiders (whether expressed in their winning actual damages or freedom to continue competing) ${ }^{174}$ proved temporary. Is this conflict so serious a threat to stability that the Conimission or the national court should be concerned about proceeding as each sees best? Again, the answer is readily at hand in the immediate application for a negative attestation by any firm wishing to test the implications of that first decision. ${ }^{175}$ Even the unfortunate plaintiff caught in the particular case is not now stymied as to its other, parallel agreements. At worst, the subsequently discredited decision covers only the one agreement between these two parties. Indeed, the later Conmission decision of validity might even, depending upon local procedural rules, be available to halt the outsider's continuing competition. ${ }^{176}$ In any event, this is probably the rarest of all situations since the courts most likely to make such rulings should be able to base them on violations

172 Presumably these will be given priority of attention by the Commission; see 6 BurL. E.E.C. 49 (No. 9/10, 1963; German ed.) ; Verloren van Themaat, Gedanken zur Wettbewerbspolitik im Gemeinsamen Markt, 13 WoW 555, 560 (1963).

173 This includes patently illegal agreements and, more important, article 7 agreements. See note 59 sicpra.

174 The existence of private remedies is not yet clear. For discussions, see van den Heuvel, Civil-Law Consequences of Violation of the Antitrust Provisions of the Rome Treaty, 12 Axr. J. CoMr. L. 172, 181 (1963); Houin, Les conséquences civiles d'une infraction aux règles de concurrence, 1963 ANNALES DE IA FACUlté DE DROIT DE LIÈGE 27; Report, Doet Overtreding Door En Ondernening Van Gemeenschapsnormen, Die Op Deze Onderneming Rechtstreeks Van Toepassing Zijn, In Het Nationale Recht Een Verbods OfSchadevergoedingsactie Ontstaan, 11 Soc. Ec. WET. 590 (1963); MATÏ̈NDER, Das VERBor HORIzONTAIER WeTTBEWERBSBESCHRÄNKUNGEN UND DIE RECHTSBEZIEHUNGEN ZU DRITTEN 164-70, 203-54 (1963). On the theoretical basis of this right, see RaISER, SUMOMUM IUs SUMTa INIURIA. INDIVIDUALGERECHTIGKEIT UND DER SCHUTZ AILGEATEINER WERTE IM RECHTSLEBEN (1936).

175 See note 38 supra.

170 Alternatively, the complainant may be suing on a new distribution agreement. 
of local law, ${ }^{177}$ which of course continues to be effective. ${ }^{178}$ And it should be remembered that in all of these situations the weakness of the concept of precedent in the abstract, absent any res judicata aspects, insures that the whole problem of reliance is not so burning an issue. ${ }^{170}$

This excursion, finally, even suggests how to treat the Commission's power to exempt retroactively. ${ }^{180}$ Is it not feasible to expect that the Commission simply should not, perhaps can not, ever exempt retroactively when to do so would conflict with completed local actions? Such a ruling would be quite consistent with the Court of Justice's present approach, and would have the further virtue of being faithful to the entire wording of Regulation No. 17 and article 9(3) specifically. ${ }^{181}$ If this were acceptable, the prospective feature of exemptibility could always be treated as above, and the exemption procedure would cause no special concern. In that case the general conclusion could be drawn that there are no overriding reasons of stability or of detrimental reliance that need thwart the Commission's freedom to decide as it deems best, even if prior local decisions have pointed to opposite conclusions. Centralized enforcement would not be as urgently needed as if often clained, and the danger of overloading a still developing organization with excessive and politically volatile responsibilities would be greatly reduced..$^{182}$

\section{CONCLUSION}

The considerations adduced at the beginming of this paper all militate against a too early withdrawal of competence to apply article 85(1) from national agencies and tribunals. If in addition, as has been suggested here, the legislative command to do so is not after all a compelling one, and if the fear of inconsistency does turn out to be a hobgoblin, then it seems quite proper to expect a conservative approach to the centralized application of the Community's antitrust laws. This approach would preserve a maximun of responsibility for the national legal and judicial systems, without hindering or slowing down the functioming of the Community orgamizations.

177 This is so, for example, in France, where the specific "refusal to deal" legislation is usable against exclusive dealing agreements perhaps to a greater extent than elsewhere, and where the cases discussed in text accompanying notes 49-53 supra either were or could have been decided on that basis. See Robert, Note, [1963] DaILoz Jurusprudence 369.

178 See note 105 supra.

179 See note 117 supra.

180 Compare generally, Deringer, Kommentar, 13 WoW 269 (1963) (annot. 3).

181 See text accompanying notes 66-68 supra; Lenhoff, Jurisdictional Relationship Bctween the Court of the European Communities and the Courts of the Member States, 12 Buffalo L. Rev. 296, 303-04 (1963).

182 See the expression of disquiet in Resolution No. 8, European Parliament, Meeting of October 16, 1963 (considering the 6th Annual Report of the Commission), reported in Agence Internationale D'Information Pour La Presse, Europe Documents, No. 224 (Oct. 19, 1963); statement of Contact Committce of EEC Consumers in id., Daily Bull. No. 1737 [Euratom \& Common Market], p. 5 (Jan. 8, 1964). 